\title{
Discounts and Other Mysteries of Corporate Finance
}

\author{
Richard A. Booth
}

TABLE OF CoNTENTS

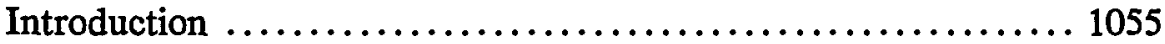

I. Dividends and Discounts........................ 1062

A. The Irrelevance Proposition ................. 1063

B. Standard Responses to the Irrelevance Proposition ..... 1064

1. The Bird-in-the-Hand Theory ................ 1065

2. The Clientele Effect ........................ 1065

3. The Signaling Hypothesis .................. 1066

C. The Downward-Sloping Demand Hypothesis ......... 1070

1. Why Internal Capital Is Cleaper .............. 1071

2. Why Investors Often Prefer Dividends........... 1073

II. Disparate Valuation............................. 1077

A. The Value of Control ....................... 1079

B. The Value of Diversification ................... 1081

III. Other Evidence of Downward-Sloping Demand .......... 1087

A. Share Repurchases ......................... 1087

B. Initial Public Offerings......................... 1091

C. Tender Offers ................................ 1095

D. Market Mechanisms............................. 1097

1. Limit Orders .......................... 1097

2. Shareliolder Vote Requirement for Certain Large Issues .................................... 1098

E. Company-Specific Phenomena................... 1099

1. Increase Accompanying Listing on the Standard \& Poors 500 .............................. 1099

2. Differing Sensitivities to Market Risk of Larger and Smaller Companies ......................... 1100

F. Marketwide Phenomena .................... 1102

IV. The Inuplications of Downward-Sloping Demand ......... 1103

A. Implications for Tender Offer Regulation........... 1104

1. The Law Should Treat Large and Sinall Companies Differently.............................. 1104

2. The Misguided Quest for Equal Treatment of Shareholders.............................. 1106 
3. The Fallacy of the "Fair Price" ................ 1107

B. Implications for Regulation of Capitalization ......... 1109

1. The Link Between Shareholder Dividend Preferences and Optimal Capitalization Levels ..... 1110

2. The Relationship Between Stock and Debt Capitalization........................... 1111

3. Regulating Capitalization Levels and the Importance of Efficiency ..................... 1112

C. Regulating Market Manipulation................. 1114

1. Explaining Stock-Specific Volatility ............. 1114

2. Reforming the Law of Manipulation............ 1114

D. The Fallacious Presumption in Favor of Fixed-Price Offerings.................................... 1116

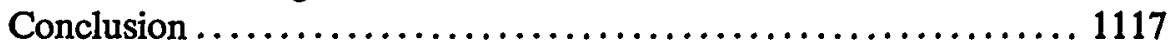




\title{
Discounts and Other Mysteries of Corporate Finance
}

\author{
Richard A. Booth $\dagger$
}

Two major theories attempt to explain why companies are often undervalued by the stock market and thus ripe for takeover attempts: the market hypothesis, which postulates that the market tends to price stocks below asset value, and the misinvestment hypothesis, which postulates that investors bid down share prices because they cannot trust managers to invest optimally. Both of these theories are believable, but they have very different implications for legal regulatory schemes. Professor Booth argues that both theories are correct and are nothing more than alternative formulations of the same basic truth: stocks, like all commodities, have downward-sloping demand curves, and their price, like the prices of other goods, is set at the margin. The downward-sloping demand hypothesis explains a wide variety of market phenomena, including why companies are often undervalued by the stock market, why the "irrelevance proposition" is untenable, and why big dividends are used to fight takeovers. Downward-sloping demand also has implications for securities regulation, particularly for the regulation of the market for corporate control. Professor Booth argues that takeover defense regulation should be more stringent for large companies than for small ones, that it may be wrong for the law to seek to treat all shareholders equivalently, and that rather than focusing on an objectively fair price for stock in corporate controversies, the law should inquire whether the parties reached a bargain that would have been expected after fair negotiation. Downward-sloping demand also suggests that stock market efficiency is an important policy goal because stock primarily functions as a dynamic indicator of value and adequacy of capitalization rather than as a static source of capital. Finally, the downwardsloping demand hypothesis also suggests that federal securities regulation acts as an elaborate price-fixing scheme that unnecessarily makes market volatility an inexplicable and sinister mystery. In sum, Professor Booth concludes that downward-sloping demand necessitates a critical reevaluation of virtually all areas of securities regulation.

\section{INTRODUCTION}

Companies are often undervalued by the stock market. While such an assertion may sound like heresy to a true behever in the sacrosanct efficient inarket hypothesis, the frequency with which tender offers arise

$\dagger$ Professor of Law, The University of Maryland, School of Law. A.B. 1973, University of Michigan; J.D. 1976, Yale University. 
at substantial premiums over market price is proof enough that the market is often wrong. ${ }^{1}$ In fact, the hefty premiums paid to shareholders do not even reflect the entire discount. Successful takeovers are often followed by the breakup of the company and the piecemeal sale of the parts at still greater profit to the bidder. ${ }^{2}$ What can possibly account for such gains if the stock market is efficient? If the market cannot be beaten even by highly sophisticated investors, and the market price thus constitutes the single best guess as to the value of a company's stock, how can it be that the market is so often incorrect? ${ }^{3}$

Commentators have recently addressed the inystery of discounts, and two major theories have emerged to explain them. One is the market hypothesis: stocks often trade at prices below the per-share value of the coinpany's underlying assets because the market tends to price stocks below asset value. ${ }^{4}$ The other is the misinvestinent hypothesis: imvestors bid down share prices because they cannot depend on managers to invest available cash flows optimally. ${ }^{5}$

1. Premiums have in fact grown steadily over the last thirty years, averaging around $75 \%$ over pre-bid market price during the period from 1974-85. See Nathan \& O'Keefe, The Rise in Takeover Premiums: An Exploratory Study, 23 J. Fin. EcoN. 101, 101 (1989).

2. See generally Lipton, Corporate Governance in the Age of Finance Corporatism, 136 U. PA. L. REv. 1 (1987) (discussing the advent and difficulties of a third stage of corporatism, "finance corporatism," wherein large pools of capital managed by institutional investors create pressure for managers to seek short-term profits). On reflection this is only to be expected: a bidder would not make a bid for a target company unless a successful bid was expected to be profitable. This means that the price paid for the target inust be somewhat less than what the bidder expects to realize from instituting operating changes or selling off assets. If the incumbent management were to take the same steps, the shareholders would enjoy all the proceeds.

3. For a concise explanation of the efficient market theory in all its forms, see J. LoRIE, P. DodD \& M. KIMPTON, THE STOCK MARKeT: Theories AND EVIDENCE 55-79 (2d ed. 1985).

4. Kraakman, Taking Discounts Seriously: The Implications of "Discounted" Share Prices as an Acquisition Motive, 88 ColuM. L. Rev. 891, 898-901 (1988).

5. Id. at 897-98. Several other explanations have been offered for why tender offers arise. The bidder may offer superior management, or the existing management may be slack. See Easterbrook \& Fischel, The Proper Role of a Target's Management in Responding to a Tender Offer, 94 HARV. L. REV. 1161, 1168-71 (1981) (arguing that the tender-offer bidding process polices managers whether or not a tender offer occurs, and disciplines or replaces them if they stray from the service of the shareholder). Bidders may habitually overpay because of the so-called "winner's curse" (i.e., the obvious fact that the most optimistic bidder typically wins), or simply because of hubris (i.e., the overestimation by the bidder of his or her own managerial skills). See Black, Bidder Overpayment in Takeovers, 41 STAN. L. REV. 597, 624-26 (1989). The premiums offered to shareholders may merely be transfers of possibly excessive returns previously paid to other constituents such as managers, employees, or bondholders. See Shleifer \& Summers, Breach of Trust in Hostile Takeovers, in Corporate Takeovers: Causes and Consequences 33, 34-37 (A. Auerbach ed. 1988); McDaniel, Bondholders and Stockholders, 13 J. CoRP. L. 205 (1988). But see Marais, Sehipper \& Smith, Wealth Effects of Going Private for Senior Securities, 23 J. Fin. EcoN. 155,186 (1989) (study of going-private proposals made from 1974 to 1985 does not indicate that wealth is being transferred from one group of seeurity holders to another). The desire to substitute deductible interest payments for nondeductible dividend payments may provide the motivation for a tender offer. However, this argument is undermined by the fact that the target company could do the same thing just as easily. See Gilson, Scholes \& Wolfson, Taxation and Dynamies of Corporate 
The market hypothesis makes sense because no single valuation model may be appropriate for both shares and assets. For example, shareholders generally do not have the power to sell the underlying assets. They inay, therefore, discount share value to compensate for the absence of this power. ${ }^{6}$ Alternatively, the trading process may create noise or bias. For example, some (perhaps much) trading may be prompted by traders watching other traders' behavior or focusing on widely accepted but possibly flawed indicators of value. ${ }^{7}$

The misinvestment hypothesis is also believable. This theory does not imply that managers necessarily mismanage their firms by failing to wring the maximum return available from assets, but rather that they tend to reinvest available casl instead of dcclaring payouts im the form of dividends, sliare repurchases, or liquidation, even when tlie return on reinvested casli is lower than the return on existing operations. ${ }^{8}$

Control: The Uncertain Case for Tax Motivated Acquisitions, in KNIGHTS, RAIDERS, AND TARGETS: The Impact of The Hostile Takeover 271, 293-94 (J. Coffee, L. Lowenstein \& S. RoseAckerman eds. 1988) [hereinafter KNIGHTS, RAIDERS, AND TARGETS] (to sustain the claim that interest deductibility encourages acquisitions, one must demonstrate why deductibility is more valuable when debt proceeds are used to make acquisitions than when proceeds are used to inake any other investment).

6. See Kraakman, supra note 4, at 899 ("share prices of firms holding liquid assets might discount asset values if traders placed an intrinsic value on the right to hiquidate firms in the asset market"); Shubik, Corporate Control, Efficient Markets, and the Public Good, in KNIGHTS, RAIDERS, AND TARGETS, supra note 5, at 31, $45-48$ (noting that the right to dispose of physical property ceases to be held by the sharelolder in the highly liquid stock market, causing the stock inarket to value the shares less highly than the market for corporate control); see also Lowenstein, Pruning Deadwood in Hostile Takeovers: A Proposal for Legislation, 83 CoLUM. L. REV. 249, 259.60 (1983) ("The traditional logic of property is simply not useful in a situation where ownership and control have been so largely divorced."); infra text accoinpanying note 76 (discussing the concept that control has value).

7. See Kraakman, supra note 4, at $899-900$ (arguing that large-scale noise trading, arising from misconceived strategies, erroneous valuation assumptions, fashions and fads, or simple pleasure in trading, miglit distort share prices and generate discounts or premiums through the slicer pressure of trading); see also Gilson \& Kraakman, The Mechanisms of Market Efficiency, 70 VA. L. REV. 549, 573-79 (1984) (discussing the process of derivatively informed trading to explain how new information enters the market). While this explanation may once have seened a bit tenuous, the 1987 crash of the stock market makes it quite believable. One journalist lias suggested that it is unimportant whether traders correctly anticipate the future course of the economy, as long as they know what their fellow traders are doing at any given moinent. However, "when traders' opinions on the workings of the economy are taken seriously by policyinakers and the financial press, dangerous things can liappen." Webb, To Understand the Economy, Ignore Traders, Wall St. J., Aug. 24, 1989, at A10, col. 3.

8. See Kraakman, supra note 4, at $897-98$ (suggesting that under the misinvestment hypothesis, "[i]f managers are reluctant to distribute these cash flows and are unable-or unwilling--to discover profitable new investments, shareholders inust inevitably price firms at below informed appraisals of their asset values"); see also Coffee, Shareholders Versus Managers: The Strain in the Corporate Web, 85 MICH. L. REV. 1, 21-22 (1986) (citing studies that suggest managers are overly biased toward earnings retention, with the rate of return on internally generated funds well below that on debt or equity); Jensen,.Agency Costs of Free Cash Flow, Corporate Finance, and Takeovers, 76 AM. EcoN. REV. 323, 328 (1986) (proposing free cash flow theory, which implies that managers of firms with unused borrowing power and large free cash flows are more likely to 
Both of these explanations are consistent with market efficiency in the sense that the market immediately assimilates all available information, thus making it impossible to identify "misvalued" stocks. However, the two theories lend different degrees of support to the idea that market price constitutes the best guess as to a company's true value. ${ }^{9}$ The market hypothesis runs counter to the idea of market accuracy in suggesting that equilibrium prices may be set by a mixture of accurate and inaccurate signals. On the other hand, the misinvestment hypothesis seeins to support the idea of market accuracy because, although shareholders might prefer payouts over the investment strategies pursued by inanagers, the less preferred strategies can nonetheless be valued.

The two hypotheses also have vcry different implications for how tender offers and defensive tactics should be regulated. If the misinvestment hypothesis is correct, tender offers should be encouraged and defensive tactics condemned since such a pohicy would encourage distributions and discourage reinvestment of available funds at inferior returns. If the market hypothesis is correct, a contrary policy would seem to be inore appropriate because discounts arise as a result of peculiarities of market mechanisms and through no fault of managers.

The thesis of this Article, however, is that both explanations are correct, and indeed that both explanations are nothing more than alternative formulations of the sanie basic truth: stocks, like other commodities, have downward-sloping demand curves. ${ }^{10}$ In other words, the price of a share for purposes of the trading market is established by the lowestvalumg current shareholder or, stated another way, the highest-valuing potential shareholder while the price of a share for the purposes of a tender offer or other acquisition is set by the highest-valuing current

undertake low-benefit or even value-decreasing mergers and acquisitions); Lehn \& Poulsen, Free Cash Flow and Stockholder Gains in Going Private Transactions, 44 J. FIN. 771 (1989) (providing einpirical evidence suggesting that going-private transactions are triggered by undistributed cash flow).

9. For other works striking a distinction betwecn these two ideas of efficiency, see Booth, Management Buyouts, Shareholder Welfare, and the Limits of Fiduciary Duty, 60 N.Y.U. L. REV. $630,633-38$ (1985) (discussing these concepts in the context of a management buyout); Gordon \& Kornhauser, Efficient Markets, Costly Information, and Securities Research, 60 N.Y.U. L. REv. 761, 770 (1985) (explaining that prices are efficient in two senses: (1) the current price of a security best predicts its future price, and (2) the prevailing price immediately assimilates all available information); Wang, Some Arguments that the Stock Market Is Not Efficient, 19 U.C. DAVIS L. REv. 341, 344 (1986) (distinguishing "information arbitrage" efficiency from "fundainental valuation" efficiency). But $c f$. Stout, The Unimportance of Being Efficient: An Economic Analysis of Stock Market Pricing and Securities Regulation, 87 MrCH. L. REv. 613, 696-706 (1988) (blurring the distinction between the two types of market efficiency and arguing that inarket efficiency should make little difference as to how the securities markets are regulated).

10. Regarding the concept of demand generally, see R. POSNER, ECONOMIC ANALYSIS OF LAw 4-5 (3d ed. 1986). 
shareholder or highest-valuing bidder. In short, the price of stock, like the prices of other goods, is set at the margin.

The downward-sloping demand hypothesis predicts that most shareholders value their shares at a price that is higher than the market price. In other words, the market may be said naturally to undervalue shares. Downward-sloping demand also implies a good deal of shareholder distrust of management. The more stock a company wants or needs to sell, the greater the discount it must offer because each next investor is sliglitly more pessimistic about the company's prospects. That is, the market undervalues stock because the last sliare is necessarily sold to an investor who perceives the greatest risk, including the risk of managerial malfeasance.

Surprisingly, the idea that individual stocks lave downward-sloping deinand is quite controversial. ${ }^{11}$ It is generally assumed within the academic community that a well-diversified investor who follows the dictates of the efficient market theory will be indifferent among various stocks. Such an investor is a rational price-taker who declines to waste time and effort in the futile attempt to pick undervalued stocks. Furtler, it is argued that a rational investor would choose to sell for any premium that might be offered unless market imperfections, such as defensive tactics and laws that discourage takeovers, make it rational to hold out for a bigger premiuin.

All this has been taken to mean that the demand curve for stocks is horizontal, or, if one prefers, that the supply curve is vertical. According to this premise, investors will buy large amounts of stock from an issuer without bidding down the price, and will likewise tender large quantities of stock to an offeror without bidding up the price. Moreover, since the rational investor diversifies, one stock is a pretty good substitute for any other. Thus, purchases and sales of a particular stock should lave little if any effect on the price of that stock. ${ }^{12}$

11. For a more detailed discussion of the theory that stocks have a horizontal demand curve, see infra notes $69-71$ \& 81-82 and accompanying text.

12. Despite the general acceptance of this theory, there is a growing body of work implicitly based on the idea that stocks do or may have downward-sloping demand. See, e.g., M. Fox, Finance ANd Industrial Performance in A DYNamic Economy 23-24 (1987) (rejecting the neoclassical assumption of homogenous expectations betwecn management and participants in the financial process); Baysinger \& Butler, Antitakeover Amendments, Managerial Entrenchment, and the Contractual Theory of the Corporation, 71 VA. L. REv. 1257, 1283-88 (1985) (arguing that due to shareholder heterogeneity, tender offers have differential welfare effects on different shareholders); Bebehuck, Toward Undistorted Choice and Equal Treatment in Corporate Takeovers, 98 HARv. L. REv. 1693, 1719-20 (1985) (explaining that when there is a tender offer, shareholders differ in their estimates of the independent target's value); Brudney \& Chirelstein, A Restatement of Corporate Freezeouts, 87 YALE L.J. 1354, 1359 (1978) (in a two-step merger, stockholders of the acquired company will hold heterogeneous views on the intrinsic value of its shares); Burnovski, Reverse Price Tender Offers, 56 GEO. WASH. L. REv. 295, 302-07 (1988) (adopting the upward-sloping supply curve to describe reverse-price tender offers); Carney, Fundamental Corporate Changes, Minority 
It is not so clear, however, that even well-diversified investors do or should remain indifferent when a stock they hold is "in play." The logic of the efficient market and diversification does not apply to the bidders who buy control of whole comparies. Bidders expect increased

Shareholders, and Business Purposes, 1980 AM. B. Found. RES. J. 69, 112-18 [hereinafter Fundamental Changes] (analyzing gains and losses to shareholders in squeeze-out mergers, assuming an upward-sloping supply curve); Carney, Shareholder Coordination Costs, Shark Repellents, and Takeout Mergers: The Case Against Fiduciary Duties, 1983 AM. B. FouND. REs. J. 341, 353-57 (arguing that perfectly elastic supply curve does not fully explain target shareholder behavior); Chazen, Fairness from a Financial Point of View in Acquisitions of Public Companies: Is "Third-Party Sale Value" the Appropriate Standard?, 36 Bus. LAw. 1439, 1479-81 (1981) (proposing that an evaluation of the financial fairness of a tender offer must include an estimate of the price range within which the company could be sold to other prospective purchasers); Coffee, Regulating the Market for Corporate Control: A Critical Assessment of the Tender Offer's Role in Corporate Governance, 84 CoLUM. L. REv. 1145, 1178-83 (1984) (arguing that the market for corporate control is inelastic); Fischel, Efficient Capital Market Theory, the Market for Corporate Control, and the Regulation of Cash Tender Offers, 57 TEx. L. REV. 1, 19 (1978) (discussing the effect in a free market economy of incremental differences in price on the willingness of stockholders to sell); Kanda \& Levmore, The Appraisal Remedy and the Goals of Corporate Law, 32 UCLA L. REV. 429, 437.41 (1985) (explaining how the appraisal remedy protects inframarginal valuations understated by market price); Levmore, Efficient Markets and Puzzling Intermediaries, 70 VA. L. REv. 645, $651-57$ (1984) (arguing that there is no evidence for elasticity of demand for inframarginal shares, and that elasticity of deinand is reduced by disparate tastes for risk diversification, tax advantages, and particular management strategies); Stout, supra note 9, at 687-88 (noting that refusing to sell at the current market price is how current shareholders state that they think the value of their shares exceeds the market value); Stout, Are Takeover Premiums Really Premiums? Market Price, Fair Value, and Corporate Law, 99 YALE L.J. 1235, 1244-52 (1990) [hereinafter Takeover Premiums] (rejecting belief that investor demand is nonexistent at prices above the current market price and infinite at prices below); see also Booth, Is there Any Valid Reason Why Target Managers Oppose Tender Offers?, 14 SEC. REg. L.J. 43, 50 (1986) ("Presumably, stocks-like everything else-have downward-sloping demand curves ... ."); Booth, supra note 9, at 633-38 (vast majority of shareholders must beheve that their stock is worth more than the market price, with manageinent's valuation the highest because of reduced risk exposure); Booth, The New Law of Freeze-Out Mergers, 49 Mo. L. REv. 517, 544 \& u.155 (1984) [hereinafter Freeze-Out Mergers] (stating that in order for stock market to function, there must be a range of values perceived by traders and potential traders); Booth, The Problem with Federal Tender Offer Law, 77 CALIF. L. REv. 707, 716 \& n.32 (1989) [hereinafter Federal Tender Offer Law] (arguing that stocks subject to takeover bids have downward-sloping demand curves).

Professor Coffee has discussed the imphications of an upward-sloping supply curve, describing the imclination of shareholders to tender as dependent on the premium offered. Coffee, supra, at 1185; see also Fundamental Changes, supra, at 112-15 (using upward-sloping supply curve to measure losses to target shareholders in squeeze-out merger). Coffee's supply curve and my demand curve are nothing more than two different perspectives: be views the shareholders as supplying increasing quantities of shares for increasing premiums offered, while I view the shareholders as demanding higher premiums as publicly held shares are tendered and become scarce. I must admit that I originally thought of the curve as an upward-sloping supply curve. See Freeze-Out Mergers, supra, at 551-53. However, I find that a maximum tender price is more realistically estimated by the point on a demand curve where supply equals zero, than the point on a supply curve wliere shareholders could continue, at ever-increasing prices, to tender shares that do not exist. Moreover, the demand curve more effectively explains why new issues of stock have a price-depressing effect. But whatever one calls it, the idea is the same. See Takeover Premiums, supra, at 1247 (arguing that deinand for stock is downward-sloping from the perspective of buyers, and upward-sloping from the perspective of sellers); Stout, supra note 9, at $688 \mathrm{n} .373$ (same).

13. "In play" is industry jargon meaning that the company is up for sale. 
company-specific returns to compensate them for forgoing valuable diversification. Thus, bidders generally beheve that target companies are undervalued. And as for investors, when there is a bidder or potential bidder lurking about who is interested in gaining control of a target company, investors may act, quite rationally, on the basis of the value beheved to be perceived by the bidder. In other words, when a contest for control arises, demand is no longer horizontal and supply is no longer vertical. ${ }^{14}$

The notion that there is a single correct price for a share of stock is usually associated with the efficient market hypothesis. There is, however, nothing inconsistent between the idea that the market is efficient, in the sense that it cannot be beaten, and the idea that shareholders may hold different opinions about the value of a particular stock. There is no reason why, other things being equal, very different equilibrium prices would not be established for the sanie security at different levels of supply. Indeed, ultiniately it is the idea that a company cannot be worth more than its market price that does not withstand analysis.

Even if downward-sloping demand implies that the inisinvestment hypothesis and the market hypothesis are simply different ways of looking at the sanie phenomenon, and that there is no need to choose between the two hypotheses, it is not clear whether tender offers should be encouraged or discouraged. Rather the downward-sloping demand for stocks suggests a whole new set of regulatory solutions that are inissed, or at least inisunderstood, if one insists on viewing tender offers from one or the other of the alternative explanations.

This Article proceeds first by presenting in Part I an extended exan1ple of how downward-sloping demand can explain a common tactic used by target coinpanies to defend against hostile takeover bids, nainely financial restructuring imvolving large borrowings and hefty one-tinie dividends. This Part begins with the "irrelevance proposition," a virtual axiom of modern financial theory, which holds that a shareholder is indifferent to dividends. According to this theory, borrowing on the part of the target in order to pay a big dividend should have no effect on the outcome of a takeover battle. The central problem with the irrelevance proposition, however, is that it assumes that tlie next share of stock can be sold without any effect on market price. Thus, when downward-sloping demand is taken into consideration, it becomes apparent that dividends often do matter to shareholders.

After demonstrating how the downward-sloping demand hypothesis explains why big dividends are used to fight takeovers, Part II addresses the prevailing view that the demand for stock must be level because

14. See infra text accompanying notes $69-71$. 
diversified investors who accept the efficient market hypothesis will regard many stocks as good substitutes for each other. This Article will show that both controlling and noncontrolling shareholders may, quite rationally, be less diversified than theory often assumes, and thus may be more concerned with coinpany-specific risk than theory would predict.

Part III of the Article then proceeds to explain how the downwardsloping demand curve can be applied to account for a wide variety of other inarket phenomena. The hist imcludes stock repurchases designed to increase market pricc, the underpricing of initial public offerings, tender offer premiums, the fact that stocks of different companies have differing sensitivities to market risk, and certain marketwide phenonnena such as the permanent price increases that accompany inclusion of a stock in the Standard \& Poors 500 (S\&P 500). The conclusion is that many of these phenomena cannot be explained well other than by the downward-sloping demand hypothesis.

Finally, Part IV discusses the imphications that downward-sloping demand may have for securities regulation. Of particular importance are its implications for the regulation of the market for corporate control.

\section{I \\ DIVIDENDS AND DiscounTs}

Defensive financial restructurings in response to takeover bids provide a dramatic example of shareholder preference for dividends and ultimately for the idea that market prices are set at a discount from underlying value. In a typical restructuring, the target takes on large anounts of debt to finance a large one-tinie dividend. ${ }^{15}$ For example, during the 1988 bid for Kraft, Inc., Kraft responded with a defensive proposal for a one-time $\$ 98$ per share dividend to be financed with a new issue of debt. ${ }^{16}$ Shortly thereafter, Sears, perhaps fearing that it was no longer too big to be a target, proposed a similar move. ${ }^{17}$ These deals suggest that somehow the payout of large sums of cash can counteract a market-price discount. ${ }^{18}$ However, the premise that dividends are dis-

15. See, eg., Prentice, Front-End Loaded, Two-Tiered Tender Offers: An Examination of the Counterproductive Effects of a Mighty Offensive Weapon, 39 CASE W. REs. L. REV. 389, 422 (1989) (discussing Newmont Mining Corporation's use of a one-time dividend as part of a strategy to fend off a takeover bid T. Boone Pickens orchestrated for a company called Gold Field).

16. Wall St. J., Oct. 24, 1988, at A3, col. 1 (\$9.8 billion debt increase to finance dividend to shareholders, consisting of \$84 in cash and \$14 in junk bonds, to defend against Philip Morris tender offer).

17. See Wall St. J., Nov. 1, 1988, at A3, col. 1 (sale of Sears Tower to finance repurchase of $10 \%$ of stock to boost earnings and stock prices).

18. See Kraakman, supra note 4, at 914-20 (arguing that discounts arising under the misinvestment hypothesis or the market hypothesis are eliminated by disbursements to shareholders). 
count-motivated runs counter to the belief held by financial economists that dividends are, or should be, irrelevant to shareholders.

\section{A. The Irrelevance Proposition}

Although the conventional wisdom among market professionals is that dividends are important to shareholders, ${ }^{19}$ in a landmark 1961 article Professors Miller and Modigliani demonstrated (at least to the satisfaction of most academics) that a company's dividend policy should be irrelevant to the company's value and therefore a matter of indifference to its sliareholders. ${ }^{20}$ They essentially argued that if a company can remvest free cash at a return equal to the company's current returu, then the sliareholders should be indifferent to whether the company pays a dividend or reinvests the available cash.

For example, assume the company generates $\$ 100$ in cash per year that it ordimarily pays out as a dividend. Assume further that a $10 \%$ capitalization rate is appropriate, making the company worth $\$ 1,000{ }^{21}$ Now suppose the coinpany discovers an investment opportumity that would require an imvestinent of $\$ 100$ and would generate a perpetual $10 \%$ return, the same return it is currently generating on $\$ 1,000$. If the company pays the dividend, the shareholders would have $\$ 100$ in cash plus the old business worth $\$ 1,000$. If the company keeps the cash and makes the investment, the sharebolders now have stock worth $\$ 1100$. Either way, the shareholders are equally well off.

Moreover, the decision to pay or reinvest is completely independent of whether the company undertakes the project or disburses cash to shareholders. If the company retains the casli, the shareholder who wants a dividend can sell some stock. ${ }^{22}$ Suppose in the given exainple

19. See, e.g., V. Brudney \& M. Chirelsten, Cases and Materials on Corporate FinANCE 528-33 (3d ed. 1987) (plan to replace cash dividend with stock dividend withdrawn after complaints by trusts, banks, and securities firms).

20. Miller \& Modigliani, Dividend Policy, Growth, and the Valuation of Shares, 34 J. Bus. 411 (1961).

21. The value of a going concern is generally calculated by dividing the income of the firm by an interest rate, often called the capitalization rate, which is equal to the rate of return that would be required by investors givcn the riskiness of the enterprise. For an explanation of valuation, see W. Klein \& J. Coffee, Business ORganization and Finance 241-62 (2d ed. 1986); J. LoRie, P. DODD \& M. KIMPTON, supra note 3, at 88-95.

22. Needless to say, a shareholder will only be able to sell some shares if the company is publicly traded. Moreover, by selling a few shares the shareholder will dilute whatever controlling interest she has in the coinpany. Thus, the irrelevance proposition has little application for closelyheld corporations. Indeed, much of the recent evolution in the law regarding closely-held corporations is based on the recognition that a shareholder in such an enterprise has no access to financial return if the company does not inake distributions. See, e.g., Wilkes v. Springside Nursing Hoine, Inc., 370 Mass. 842, 849-50, 353 N.E.2d 657, 662-63 (1976) (noting that since there is no ready market for uninority stock in a close corporation, terminating a minority stockholder's employment effectively denies an equal return on investment). 
there was only one shareholder. She could sell $\$ 100$ worth of stock to raise the cash and still keep stock worth $\$ 1,000$. If on the other hand the company paid the dividend, it could still undertake the investinent by issuing another $\$ 100$ worth of stock. Within this model, therefore, dividends are irrelevant. ${ }^{23}$

It is important to note that the irrelevance proposition is not a theory founded on the unrealistic assumption that there are no transaction costs. Rather the transaction costs involved appear roughly to balance regardless of whether the company chooses to pay dividends. If the company pays dividends and issues more stock to fund its investment opportunity, it must pay an investment banker to do so. If the company retains its cash and the shareholder sells some shares to obtain a cash return, the shareholder inust pay brokerage commissions. Either way, there are significant expenses. ${ }^{24}$

The irrelevance proposition is at odds with the idea that a large dividend can be used to defend against a takeover. Target management hopes that payment of a dividend will be more attractive to the shareholder than a takeover preimum. Yet the irrelevance proposition tells us that shareholders do not care about dividends. Thus, it seems to imply that financial restructuring cannot work to fend off a bidder. But sometimes it does. A question therefore naturally arises: what is wrong with the seemingly unassailable logic of the irrelevance proposition?

\section{B. Standard Responses to the Irrelevance Proposition}

The irrelevance proposition has generated considerable controversy, and numerous theories have been advanced to disprove it. ${ }^{25}$

23. For other similar characterizations of the irrelevance proposition, see V. BRUDNEY \& $M$. ChirelsteIn, supra note 19, at 488-92; W. KLEIN \& J. CoFFEE, supra note 21, at 303-06 (arguing that the total value of a firm is determined by investment policy, not dividend policy); Brudney, Dividends, Discretion, and Disclosure, 66 VA. L. REV. 85, 86-87 (1980) (suggesting that dividend policy is simply the residual of investment policy and, as such, irrelevant to share prices); Fischel, The Law and Economics of Dividend Policy, 67 VA. L. REv. 699, 701 (1981) ('Because a firm's dividend policy ... is simply a decision as to how the firm's real value sould [sic] be packaged for distribution, it should have no effect on share prices.").

24. See Fischel, supra note 23, at 704 (arguing that in the aggregate, transaction costs will not cause shareholders consistently to prefer either dividends or retention).

25. See, e.g., Brudney, supra note 23, at 85-97 (discussing the irrelevance proposition in hight of opposing theories and einpirical evidence, and concluding that shareholders are not indifferent to dividends); Fischel, supra note 23, at 701-09 (addressing the irrelevance proposition and various theories that have been advanced in opposition, but concluding that, apart froin the effect suggested by the signaling hypothesis, dividend policy has no impact on stock prices and therefore shareholders should be indifferent to dividends). 


\section{The Bird-in-the-Hand Theory}

It has been suggested that shareholders prefer dividends over retention of funds by a corporation because dividends are a "bird-in-thehand." The idea is that it is safer to take a cash dividend than to leave funds invested in the coinpany. ${ }^{26}$ The fatal flaw in this reasoning, however, is that risk has already been factored into the equation.

Consider the choice between a $\$ 1,000$ investment in a common stock paying a $\$ 100$ annual dividend over time versus $\$ 1,000$ deposited in a guaranteed savings account paying $\$ 100$ annually in interest. Over the last five years the stock has paid $\$ 100, \$ 80, \$ 100, \$ 120$, and $\$ 100$ in dividends. Clearly the savings account is preferable because even though the $\$ 100$ dividend is the very best estimate of what the stock will pay there is some chance it will pay less, although on average it will not pay more. The rational, risk-averse investor would always choose the savings account. As a result, the stock could not be sold for $\$ 1000$, but would be discounted in the market to make up for its relative unpredictability. Risk is thus built into the value of an investment and the argument that dividends are a bird-in-the-hand is, $m$ the end, nothing more than sleight of hand. It amounts to a denial that the investment in the corporation is really worth as inuch as it is worth. ${ }^{27}$

\section{The Clientele Effect}

A second and somewhat more persuasive argument for shareholder preference for dividends is that investors are attracted to particular stocks on the basis of personal payout preferences, nicluding the nicome, growth, or tax status of payouts. This is known as the chentele effect. ${ }^{28}$ It stands to reason that, other things being equal, a high-tax-bracket investor may prefer to invest im companies that retain their cash, allowing the payment of tax to be postponed until sale of the appreciated stock. Conversely, a low-tax-bracket investor may prefer the cash dividend. Although the taxation of dividends is commouly used to illustrate the chentele effect, it is not the only factor that may attract a particular

26. See Fischel, supra note 23, at 702-03.

27. See id. at 703-04 (contending that the bird-in-the-hand theory is erroneous because shareholders who actually preferred a bird-in-the-hand dividend to the corporation's investments in terms of risk would reduce their investment in the firm by selling part or all of their holdings). For a discussion of the definition of investment risk, see W. KLEIN \& J. COFFEE, supra note 21, at 190-98. On the measurement of risk, see J. LORIE, P. DODD \& M. KLIMPTON, supra note 3, at 108-31.

28. See Fischel, supra note 23, at 704-06. Several einpirical studies purport to support the clientele effect, although the evidence is in conflict. Id. at 706-08. The problem with these and all empirical studies is that if the phenomenon in question exists, it may be impossible to pick it out of the background. That is, the clientele effect could be so overwhelmingly strong (and the inarket so efficient) that deviations from it virtually never occur and when they do, they are so well anticipated that the eventual announcement of the dividend range is anticlimactic. 
investor to a particular stock. Investors may prefer cash or growth simply because they do or do not depend on their stocks for current income. Even a casual look at the financial press reveals that imvestments are promoted to mvestors on the basis of such characteristics. ${ }^{29}$

The chentele effect is based on the assumption that investors with similar preferences are attracted to similar types of stocks. Manageinent thus becomes imphicitly bound to satisfy the investors it has attracted in an effort to prevent thein froin selling their holdings and driving down the price of the stock. This theory has intuitive appeal. However, it is difficult to beheve that shareholders of a dividend-paying company would prefer to have the company forgo an attractive mvestment opportunity so as to pay a current dividend.

For example, imagine a shareholder with 10,000 shares of stock in some coinpany. The current inarket price is $\$ 10$ per share and the conlpany pays a $\$ 1$ per share annual dividend. If the conipany omits the dividend to finance a new project, the shareholder inust sell 1,000 shares to generate the equivalent of a dividend. The commission on the sale at $0.5 \%$ will be $\$ 50$. In order for the shareholder to break even, the company's new project need only be worth $\$ 1,050$ for each $\$ 1,000$ invested. Assuming the company's existing operations generate the same $10 \%$ return as is paid out in dividends, the new project need only yield $10.5 \%$ in order to keep the shareholders happy. Thus, with current brokerage commissions of as hittle as $0.5 \%$, there is hittle reason for a shareholder to object to a company's withholding of dividends.

Furthermore, if the shareholders have invested in a portfolio of stocks, as is the rational thing to do, it may not even be necessary to sell a few shares to replace a missing dividend. In all likelihood there will be soine companies paymg higher dividends than expected to balance out those paying lower dividends. However, no such cushioning effect will protect a dividend-paying company that must issue new shares to raise needed capital. That is, the underwriting fees that inust be paid to issue stock are an absolute loss to shareholder wealth. Thus, other things being equal, it is preferable to use internal funds for new investment, and the chentele effect, if it exists at all, must be weak indeed.

\section{The Signaling Hypothesis}

A third argument agamst the irrelevance proposition is that dividends convey otherwise unobtamable information to shareholders about a coinpany's prospects. ${ }^{30}$ The notion is that other forms of information

29. For example, the Wall Street Journal reports Lipper Indexes daily for growth funds, growth and income funds, equity income funds, balanied funds, gold funds, science and technology funds, and international funds. See, e.g., Wall St. J., Apr. 15, 1991, at C18, col. 3.

30. See Brudney, supra note 23 , at $108-14$ (citing the potential for sending misleading signals 
about a firm's prospects are less reliable than clianges in dividend policy. To be sure, botli financial accounting and the prosaic projections of manageinent are subject to a good deal of manipulation, and manageinent can be expected to make things look as good as possible. But dividends, and in particular changes in dividends, require a company to put its money where its mouth is. ${ }^{31}$ Any company can claim financial health, but a coinpany that is really doing better ought to be able to extract more cash and pay it out. ${ }^{32}$ By the same token, a reduction in dividends, that is, a failure to keep up the announced payout pace, is an undeniable signal that things may be taking a turn for the worse. Indeed, Miller and Modigliam themselves acknowledged the possibility that the message implicit in dividend clianges may cause a reaction in tlie stock inarket. ${ }^{33}$

The signaling hypothesis lias turned out to be consistent with empirical data. ${ }^{34}$ Clianges in dividend policy do indeed affect stock prices. That does not necessarily inean, lowever, that the information content of dividends triggers price clianges. The inore likely explanation is the simpler one, that shareliolders prefer bigger dividends. But that, of course, directly contradicts the irrelevance proposition itself. ${ }^{35}$

Empirical studies aside, the signaling hypothesis is open to serious

through dividend policy); Fiscleel, supra note 23, at 708-09 (arguing that clianges in dividend policy can send signals to investors about the firm's prospects, thereby affecting share prices).

31. Although the irrelevance proposition speaks to the issue of the existence of a general shareholder preference for dividends, the key issue is low shareliolders react to changes in dividend policy. Presumably no one would fault a company that las successfully reinvested its funds at returns in excess of the dividend rate it could have paid. Similarly, no one would disagrec that a company that has no use for its funds as attractive as its current operations should pay maximum dividends. See infra text accompanying note 64 . The only true issue then is whether shareholders prefer dividends or growth in companies that face growth opportunities exactly equal to their current rate of return. The question is this: how would the shareholders react to a new poicy of withliolding dividends in favor of new investinent, or vice versa?

32. In addition, a company that plans new investment while maintaining dividend payments generally must issue new stock or debt, resulting in close scrutiny of the company's financial condition through the rigorous registration process or the in-house review conducted by commercial lenders. See T. Copeland \& J. Weston, Financial Theory and Corporate Policy 496 (2d ed. 1983). For a discussion of the theory that sliareliolders prefer stable dividends so as to require a complete accounting for any new investment through the registration process, see infra text accompanying notes $43-46$.

33. See Miller \& Modigliani, supra note 20, at 418-19 (cautioning that uncritical application of the "stream of dividends" approach to stock valuation leads to the unwarranted inference that a firm's dividend policy will affect the current price of shares); see also Norris, Market Place: On Dividends, Some Fresh Hope, Wall St. J., Jul. 2, 1991, at D8, col. 2 (discussing the reluctance of corporate boards to cliange dividend structure because of the potentially negative impact on the price of stock if dividends must ultimately be adjusted downward); Hilder, Manufacturers Hanover Hints It May Cut Dividend, Wall St. J., Oct. 26, 1990, at C8, col. 5 (describing substantial decline in price of Manufacturers Hanover stock resulting from announcement).

34. See Fiscliel, supra note 23, at 709 (describing the results of several studies testing the signaling hypothesis).

35. Althougl the irrelevance proposition lias never been proven einpirically, scveral studies lave failed to find any shareholder preference for dividends. See id. at 706-07. 
question. First, it is unclear how manipulable earnings really are. Although the precise net imcome figure ultimately announced by a company and its accountants is subject to a wide variety of discretionary choices largely within management control, typically there is enough raw information available for an analyst to refigure the bottom line based on an alternative accounting inethod regarded by the analyst as more appropriate. $^{36}$ Indeed, studies indicate that accounting methods have little or no effect on the market price of a company's stock. ${ }^{37}$

Second, dividends themselves are subject to a good deal of manipulation. Legally, a corporation may pay dividends in most states as long as its balancc sheet shows an excess of assets over liabilities and stated capital plus capital surplus. That is, a company may ordinarily pay dividends as long as it shows retained earnings or otlier surplus and as long as the dividend payment does not render the company unable to pay its bills as they beeome due. ${ }^{38}$ Thus, for example, a company witl a long history of profitability may be able to increase its dividend payout even tlough its business lias not changed or is on the downturn. ${ }^{39}$

Third, it is unclear what information a dividend conveys. If with-

36. See generally J. LoRIE, P. DODD \& M. KIMPTON, supra note 3, at 96-107 (discussing the divergence between economic and accounting conceptions of earnings); S. SIEGEL \& D. SiEGEL, accounting and Financial Disclosure: A Guide to Basic Concepts 105-17 (1983) (describing the inost commonly used analytical tools for evaluating the financial condition of a firm).

37. See P. GRIfFin, Usefulness to Investors and Creditors of Information Provided By Financial Reporting 176-81 (Fin. Aecounting Standards Bd. 2d ed. 1987) (reporting that studies on the price effects of accounting-method changes fail to show a definite correlation); J. LORIE, P. DODD \& M. KIMPTON, supra note 3, at 96-107; cf. Nathan, Do Firms Pay to Pool?: Some Empirical Evidence, 7 J. AccT. \& PUB. PoL'y 185 (1988) (arguing that the rule restricting the accounting method for assets of a target company has no effeet on the stock price of the target company).

There is nothing at all inysterious about the market's ability to see through accounting conventious and changes in thein. For example, the Financial Accounting Standards Board recently proposed that greenmail payments in excess of the fair value of the stock repurchased, if paid in compensation for other rights such as the abandonment of acquisition plans, inust be regarded as a current expense rather than simply a retirement of stock. See FASB Issues Final Technical Bulletin on Accounting for Greenmail Purchases, $18 \mathrm{Sec}$. Reg. \& L. Rep. (BNA) No. 2, at 55 (Jan. 10, 1986). Under the rule, any such payment has the effect of reducing current earnings. There is absolutcly no reason, however, to think that the accounting treatinent of greenmail affeets the perception of market analysts as to the impact that the transaction may have on the financial health of the company. Nevertheless, the popular press as well as academic coinmentators and the courts continue to focus on "earnings" as perhaps the primary determinant of stock prices without recognizing that, as a measure of a firm's performance, it is at best an approximation that ought to be approached critically whenever there appears to be a potential for manipulation of the bottoin line. See, e.g., Smith v. Van Gorkom, 488 A.2d 858 (Del. 1985) (in light of the possibility that the market's focus on earnings may have ignored the greater cash-flow value of the target company, the target's directors were liable for failing to evaluate and test adequacy of market-based offering price); Kamin v. American Express Co., 86 Misc. 2d 809, 383 N.Y.S.2d 807 (N.Y. Sup. Ct.), aff'd, 54 A.D.2d 654, 387 N.Y.S.2d 993 (1976) (finding directors not hable for forgoing opportunity to reduce tax hability in order to prescnt higher corporate earnings figures).

38. See, e.g., ReviSEd MOdel Business CoRp. Act $\$ 6.40(c)$ (1984).

39. See infra text accoinpanying notes 186-92; see also Turner, Disney Increases Dividend, 
holding dividends is a cheaper way to raise capital than a new issue of stock, as is widely thought, ${ }^{40}$ then, far from indicating that the company's prospects are good, the dividend may simply mean the company cannot find a good use for its money. ${ }^{41}$ In other words, while a dividend might intuitively seem to signal good news, it might, in fact, signal bad news.

Fourth, a company whose prospects are good and whose profits are growing cannot always pay a dividend and remain solvent without selling more stock. Because earnings are accounted for by the accrual method whereas dividends are paid in cash, a growing company may need its cash, for example, to pay for the increased imventory that has been ordered to replace the sold inventory that generated the profit on which the dividend was based. ${ }^{42}$ Thus, dividends are not only manipulable by a company with a profitable past; they are often unwise for a company with a profitable future.

Finally, consider the theory that stockholders prefer dividends because they like to see companies run the gauntlet of registration when making new investments. ${ }^{43}$ The theory is based on the assumption that the quality of disclosure is better for new issues than it is for routine reporting about existing operations. Although that theory once may have been true, it is unclear that it now is. The legal penalties for misstatements continue to be most severe im counection with a new issue. ${ }^{44}$ However, companies that are already publicly traded, and hence widely followed in the market, are now free to sell additional stock with minimal new disclosures beyond normal periodic reports. ${ }^{45}$ These reforms in the

Warns Growth Could Slow, Wall St. J., Mar. 20, 1991, at B3, col. 3 (reporting increase in dividends coupled with a prediction that earnings would be disappointing).

40. See infra note $\mathbf{4 9}$ and accompanying text.

41. See Holusha, Are We Eating Our Seed Corn?, N.Y. Times, May 13, 1990, $\$ 3$ (Business), at 1 (arguing that companies that buy back their own stock lack long-term thinking and coinpetitiveness because there are inore productive things to do with the money, such as investing it in research and development of new technology).

42. See S. Siegel \& D. Siegel, supra note 36, at 118-19 ("Despite substantial net income, a company with continued negative cash flow may face bankruptcy, since it inay be incapable of paying its creditors on time.").

43. See supra note 32.

44. See, e.g., Securities Act of 1933, 15 U.S.C. $\$ 77 k(a)$ (1988) (requiring a higher burden of proof when the securities were acquired after the issuer has made "generally available to its security holders an earning stateinent covering a period of at least twelve months beginning after the effective date of the registration stateinent").

45. Some companies that are required to file periodic reports inay use the more abbreviated registration Forms S-2 and S-3 when issuing new stock. See Securities Act Form S-2, General Instructions, reprinted in 2 Fed. Sec. L. Rep. (CCH) \ 7142, at 6231-32 (1990); Securities Act Form S-3, General Instructions, reprinted in 2 Fed. Sec. L. Rep. (CCH) If 7152, at 6251-52 (1990). Under these forms, companies may incorporate (by reference) the information in their annual and quarterly reports. Securities Act Form S-2, Itein 12, reprinted in 2 Fed. Sec. L. Rep. (CCH) II 7143, at 623435; Securities Act Form S-3, Item 12, reprinted in 2 Fed. Sec. L. Rep. (CCH) II 7153, at 6255. All 
registration system affect the largest public companies ${ }^{46}$ that, because they are most distant from their investors, are presumably the same companies to which the signaling hypothesis is said to apply. In short, for larger companies the kind of disclosure required in connection with a new issue of stock varies hittle from the kind of disclosure that is already required on a routine basis.

\section{The Downward-Sloping Demand Hypothesis}

None of the foregoing arguments agaimst the irrelevance proposition is persuasive. Yet the irrelevance proposition still seems paradoxical. First, the irrelevance proposition is at odds with the idea that it is cheaper to raise new capital imternally than it is to sell new stock. Common sense suggests that for the company to attract new investors, it must offer its stock at a somewhat lower price than the prevailing inarket price. After all, if the old business had been attractive enough for new investors they already would have bought in.

Second, the irrelevance proposition is at odds with the idea that dividends are the only way a shareholder can participate financially in a company short of hquidation. ${ }^{47}$ To be sure, one may be able to sell one's shares at a gani, but the only reason that other investors are willing to buy is that shares carry the right to dividends. ${ }^{48}$ This suggests that one of the crucial assumptions underlying the irrelevance proposition may be false, namely that a shareholder can always sell a few shares to generate a

that must be set forth expressly in the registration statement is a description of the securities offered and uses to which the proceeds will be put. See Securities Act Form S-2, Items 4, 9, reprinted in 2 Fed. Sec. L. Rep. (CCH) \ 7143, at 6232-33 (1990); Form S-3, Items 4, 9, reprinted in 2 Fed. Sec. L. Rep. (CCH) I 7153, at 6254 (1989).

Furthermore, stock may be sold for up to two years, virtually eliminating any particularized disclosure as to use of proceeds in connection with the new stock. See 17 C.F.R. $\$ 230.415$ (1990) (requirements for registering securities for a delayed offering). See generally Banoff, Regulatory Subsidies, Efficient Markets, and Shelf Registration: An Analysis of Rule 415, 70 VA. L. REV. 135 (1984) (presenting arguments for and against Rule 415, and concluding that the Rule serves the public interest); Fox, Shelf Registration, Integrated Disclosure, and Underwriter Due Diligence: An Economic Analysis, 70 VA. L. REV. 1005 (1984) (responding to Banoff, and arguing that Rule 415 diminishes the quality of information available to the public and the benefits accruing therefrom); Note, Auctioning New Issues of Corporate Securities, 71 VA. L. REV. 1381, 1392-96 (1985) (analyzing the potential legal innact of Rule 415 disclosure requirements on securities auctions).

46. For example, Rule 415 allows for the shelf registration of common stock by companies that are eligible to use Form S-3. 17 C.F.R. $§ 230.415(a)(1)(x)(1990)$. Those companies must have been registered with the SEC for purposes of continuous reporting for threc years, and have 150 million dollars in aggregate market value of common stock outstanding (or 100 million dollars with annual trading volume of three million shares or more). Securities Act Form S-3, General Instructions, supra note 45.

47. See W. KLEIN \& J. COFFEE, supra note 21, at 252-53.

48. See id. (arguing that the value of a share of common stock is most often determined solely by the amount of the expected stream of dividend payments: "In the absence of an expectation of growth in dividends there would be no reason for succeeding purchasers to bid up the price of the stock."). 
cash return equal to the withheld dividend. If a significant number of shareholders do in fact sell in order to gain current income, then the market price may be forced downward and later-selling shareholders may not be able to generate a dollar-for-dollar cash return by selling their shares. This result may be particularly likely where the sales are perceived to have been in reaction to an omitted dividend.

Both of these anomalies suggest that stocks, like other commodities, have downward-sloping demand curves. Simply put, in order to induce the next person to buy something, it must be offered at a slightly lower price. The idea that new stock could be sold to new mvestors without some added incentive assumes, in effect, that there are no differences in investor opinions, and that there is an unlimited supply of substitute investors to replace those who sell to generate a cash return.

\section{Why Internal Capital Is Cheaper}

Recent research deinonstrates that a new issue of stock does imdeed result im a decrease in market price. ${ }^{49}$ Arguably the sale of additional stock to the public imdicates that management beheves the existing stock is overvalued, and that the price depression results from the information content of the offering. ${ }^{50}$ These factors are consistent with the downward-sloping demand hypothesis. That is, one would expect the price of any commodity to fall a bit as new supply is added.

Other studies indicate that secondary offerings in the form of block sales by large sliareholders cause a significant price depression. ${ }^{51}$ The wisdom on the street had been that such sales create price pressure because buyers demand an incentive or sweetener. Because the value of

49. See Asquith \& Mullins, Equity Issues and Offering Dilution, $15 \mathrm{~J}$. FIN. EcoN. 61, 61-66 (1986) (study of announcement-day and issue-day price effects of primary and secondary issues of equity, demonstrating that equity issues reduce stock prices); Masulis \& Korwar, Seasoned Equity Offerings: An Empirical Investigation, 15 J. FIN. EcoN. 91, 91-94 (1986) (study demonstrating a significant negative price change associated with the announcement of equity offerings); Mikkelson \& Partch, Valuation Effects of Security Offerings and the Issuance Process, 15 J. FIN. EcoN. 31, 3134 (1986) (study finding statistically significant negative valuation effect at the announcement of common stock and convertible debt offerings).

The idea that inside money is cheaper than outside money is usually based on the simple observation that raising external capital involves flotation costs. See J. WESTON \& E. BRIGHAM, MANAGERIAL FINANCE 602-03 (5th ed. 1975). These flotation costs are roughly accounted for under the irrelevance proposition, since mvestors who prefer dividends must pay broker's commissions. On the other hand, a shareholder who wants to maintain his or her relative stake in a dividend-paying company that chooses to issue new stock must bear the expense of brokerage commissions, in addition to the indirect expense of the flotation expenses incurred by the company.

50. This is analogous to the idea that repurchases of stock indicate that management believes the stock to be undervalued.

51. See Dann, Mayers \& Raab, Trading Rules, Large Blocks and the Speed of Price Adjustment, 4 J. FIN. ECON. 3 (1977); Kraus \& Stoll, Price Impacts of Block Trading on the New York Stock Exchange, 27 J. FIN. 569, 570-71 (1972); Scholes, The Market for Securities: Substitution Versus Price Pressure and the Effects of Information on Share Prices, 45 J. Bus. 179, 180-81 (1972). 
the company was presumably the same before and after the block sale, the lore was that the stock would soon rebound, and that a trader could make a profit by buying immediately after such a sale, holding for a few hours or days, and then reselling. ${ }^{52}$ Instead it turns out that secondary sales lead to a permanent depression in price. ${ }^{53}$ An alternative explanation is that the sale signals a downturn in the fortunes of the company, which the market immediately impounds. Indeed, the studies indicate that the price effect differs depending on whether the block seller was an insider or a large institution, as opposed to a trust or estate, because the former are more likely to have information about the coinpany's prospects. ${ }^{54}$ Nevertheless, while the identity of the seller does make soine difference, a permanent price depression results no inatter who the seller is. ${ }^{55}$ A block sale, therefore, in addition to having a signalling effect, creates price pressure consistent with the downward-sloping deinand hypothesis. ${ }^{56}$

The argument agamst paying dividends when there is a need for capital thus appears quite strong considering that one of the crucial assumptions underlying the irrelevance proposition-that new stock can be sold at the old price to raise the necessary cash-appears open to serious question. ${ }^{57}$ If internal capital is indeed cheaper, then existing share-

52. See J. LoRIE, P. DoDD \& M. KIMPTON, supra note 21 , at 68-70.

53. See Kraus \& Stoll, supra note 51, at 570-71 (block sales result in a change in the expected rate of return and a permanent decrease in the equilibrium price).

54. Scholes, supra note 51.

55. See Dann, Mayers \& Rabb, supra note 51.

56. The recently proposed rights offering by Time Warner provides a striking example of the effect that a new issue of stock may have on the price of stock outstanding. In June, the company proposed an offering of rights to purchase new stock to its existing shareholders. The price at which the stock could be purchased was dependent on the number of rights cxercised: the more rights exercised, the higher the exercise price. The market price of Time Warner stock declined $20 \%$ in the week following announcement of the plan. Kneale \& Dorfman, Time Warner Vows to Pursue Offering Despite 20\% Stock-Price Drop in Week, Wall St. J., June 10, 1991, at B5, col. 2. Some investors argued that the offering was desigued to coerce them into buying shares in order to maintain their relative stake in the company. See Landro \& Anders, Time Warner's Rights-Offering Plan Greeted by 10\% Plunge in Stock Price, Wall St. J., June 7, 1991, at A3, col. 2. The simpler explanation is that the offering threatened to increase the supply of stock, and thus to depress its price. Moreover, the offering required existing shareholders, who had already determined how much Time Warner stock they desired to hold, to buy more or see it sold to others at bargaim prices. If the level-demand hypothesis were correct, the offering should have had no effect on stock prices, other than perhaps as a result of upsetting the diversification of portfohos that contained Time Warner stock. In the end, the offering was substantially revised. See Smith, Managers of Time Warner Revised Offer May Reap Higher Fees by Buying Rights, Wall St. J., July 22, 1991, at B4, col. 5; Landro \& Smith, After Stock Debacle Some Ask: Will Hubris Undo Time Warner?, Wall St. J., July 19, 1991, at A1, col. 6; Smith \& Landro, Time's Decision to Revise Offer Boosts Its Odds, Wall St. J., July 15, 1991, at A3, col. 1; Smith, SEC Said to Object to Price Mechanism in Time Warner StockRights Offering. Wall St. J., July 11, 1991, at A2, col. 5; Landro \& Smith, Time Warner Mulls Revising Rights Offering, Wall St. J., July 10, 1991, at A4, col. 3.

57. Moreover, the lower price at which new stock must be sold harms all existing shareholders, including those who decline to sell. For example, if a company has 100 shares outstanding that are 
holders should prefer its use to new issues of stock. Yet the irrelevance proposition is founded in part on the idea that paying dividends will not preclude the coinpany froin undertaking new projects at least as attractive as current operations. Clearly, if outside capital is more expensive than inside capital, the dividend and investment decisions are not wholly independent.

\section{Why Investors Often Prefer Dividends}

If, in fact, internal funds are a cheaper source of capital, shareholders should be distinctly averse to dividends, at least when the company is in need of capital. ${ }^{58}$ In other words, the idea that internal funds are cheaper than external funds offers no explanation for why shareholders would ever prefer dividends. But if there is no reason to beheve that investors do sometimes prefer dividends, then there is no reason to think, for example, that a coinpany's borrowing to make a hefty distribution will have any defensive effect in the face of a hostile bid.

This suggests that there nnay be another unrealistic assumption behind the irrelevance proposition, namely that management can coinmunicate adequately with shareholders about the plans it has for any cash retained. Indeed, this assumption is quite explicit. Miller and Modighiani themselves indicated that the irrelevance proposition holds only if the firm's investment policies are known to the shareholders. ${ }^{59}$

Adequately publicizing a company's plans for the future is not a simple inatter. Because predictions for the coinpany's future are often self-serving, realistically the inost rehiable information a shareholder has about the future is the company's past. This is true whether tle company has a history of paying niaximum dividends, or a record of successful reinvestment and growth. Thus, when a coinpany announces a change in dividend policy, shareholders are naturally skeptical.

However, there is more than mere skepticisn at work here. First, it is fairly well established that the stock inarket is efficient, at least in the sense that it is impossible for any shareholder to beat the market consistently without inside information. ${ }^{60}$ Second, rational shareholders diversify. By buying a portfoho of stocks, an investor avoids the risks

trading for $\$ 10$ per share and new shares can be sold to new shareholders at only $\$ 9$ per share, and if the company chooses to pay a dividend of $\$ 100$ and sell $\$ 100$ worth of new stock, a shareholder owning a simgle share of the original issue would find that the $\$ 11$ in value (the original $\$ 10$ plus a capital gain of $\$ 1$ ) is now only worth $\$ 9$ plus a $\$ 1$ dividend, or $\$ 10$ altogether.

58. See Brudney, supra note 23 , at $91-92 \&$ n.18 (noting the differences between transaction costs incurred by the corporation to issue more stock, and those incurred by investors who receive dividend payments).

59. Miller \& Modigliani, supra note 20 , at 414.

60. See J. LoRIE, P. Dodd \& M. KIMPTON, supra note 3, at 55-79 (discussing the efficientmarket hypothesis). 
attending the business of individual companies without sacrificing any return. ${ }^{61}$ The clear implication for the investor is that time and money sliould not be wasted on atteinpts to pick individual stocks. Ratlier, the investor should determine tlie level of risk and return desired, and construct a portfolio accordingly. This reasoning applies whetler the investor is making a new purchase of stock or considering a sale of stock. Thus, a rational shareholder is not likely to pay much attention to naanageinent's claims that it is undertaking a new and attractive investment prograin. Such claims, after all, are tantamount to predictions that the company's stock will do better than the market. ${ }^{62}$ But there is no reason to believe that management is any better at predicting tlie effect of a given disclosure on the stock market than anyone else, even when tlie prediction involves its own operations. ${ }^{63}$

There is, however, a still inore powerful reason why dividend oinissions for new investment are more likely to be viewed negatively by shareholders. Professors Klein and Coffee have put it most succinctly:

61. See id. at 108-31 (discussing the theory of portfolio managenent).

62. Of course, whatever manageinent says about the company becoines part of the information that the market digests, and thus will have an effect on the efficient market price, presunnably because investors do pay attention. See Gilson \& Kraakman, supra note 7, at 622-23 (noting that according to the "efficiency paradox" there is no incentive to gather information when the market is perfectly efficient since it can never be beaten, and yet when information-gathering stops, the market bccomes imefficient). This paradox can be resolved quite simply for present purposes by recognizing that the market may well react to some of the harder facts inanagement discloses, while ignoring those that are merely predictive.

63. The situation is somewhat different, of course, if the new investment is for the expansion of existing business. In that case, market efficiency would argue that the best gness as to the value of the new business is the value of the current business, although the law of diminishing returns might suggest some discount from previous levels of return. Nevertheless, managenent's naked claims that its busmess will improve are unlikely to be believed.

The omission of a dividend, on the other liand, may affect the inarket. First, if the company is a poor discloser, the dividend omission may indicate lower returns than previously expected by mvestors. Second, the omission may mcrease risk in and of itself: skipping a payout means that cash returns to shareholders have become more erratic, which is the very essence of increased risk. See W. KLEIN \& J. COFFEE, supra note 21, at 190-92. There is, admittedly, some tension between this point and the earlier refutation of the bird-in-the-hand argument. Nevertheless, it seems reasonable that an iuvestor would assess the dividend omission and the new investment program independently. Indeed, the independence of the two is one of the most commonly noted inplications of the irrelevance proposition itself. See id. at 303-06. Yet the independence of the two decisions also means that the investor may decide that the increased volatility of returns weighs more heavily than future prospects in the overall assessment of the company's value.

The traditional view is that companies that pay generous and stable dividends are more highly valued in the market than companies that do not. In addition to the counterargunents offered by the irrelevance proposition, this view may be questioned because cash dividends create the appearance of volatility. When the dividend record date arrives for a stock, its price naturally falls in the market by the anount of the distribution. One way to avoid this drop inay be to pay a stock dividend, which increases the number of shares over which the ultinate right to the accumulated value is spread. Still another means to avoid the drop and to create the appearance of a rising price is to use the aceumulated cash to make repurchases. Either of these methods would seem to reduce the danger that price fluctuatious owing to cash payments would be misread as volatility. 
A firm with substantial earnings is likely to generate spare cash-that is, cash that is not needed to maintain the existing level of investinent. Most mature firms have limited opportunities to earn acceptable returns by expansion of their existing business or by entering new businesses and are reluctant to invest in the securities of other firms. When such mature firms retain their spare cash rather than paying it out as dividends, they will therefore be likely to invest that cash in projects with low rates of return. Accordingly, the shareholders will gain from a policy of generous dividend payments. Shareholders are inconvenienced by irregular cash flows and corporate managers can without great difficulty adjust their cash resources so as to pay steady dividends. Thus, dividends should be not only generous but stable. ${ }^{64}$

If anything, Klein and Coffee understate the case. Imagine a company valued in the aggregate at $\$ 1,000$ by the stock market. The company makes $\$ 100$ per year and pays it all out in dividends. Management discovers a new process that reduces costs dramatically. Annual dividends increase to $\$ 200$. Although for a fleeting instant the company's yield has increased to $20 \%$, the market value of the firm will quickly jump to $\$ 2,000$ and the yield will fall back to $10 \%$. The same forces will operate quickly to reduce the extraordinary returns from any improvement back to market rates. This means that the company can never enjoy permanently enhanced returns, and any further investment in the busmess must be judged solely on its own merits. These observations may seem obvious or even trivial, but they have profound implications. The fact that the extraordinary returns of any innovation are quickly dissipated means that competition among managers for opportumities must be keen indeed. Investors are thus quite justified in their skepticism of management claims.

Recent research also bears out the idea that investors are naturally skeptical of management claims. Studies indicate that bad news has a greater effect on market prices than does good news. ${ }^{65}$ This is a surpris-

64. Id. at 300 . See also Brudney, supro note 23 , at 95 ("Possibly a mature firm's capacity to expand tends to be limited, so that at the margin new investment will produce a lower return than the existing business." (footnote omitted)).

65. See De Bondt \& Thaler, Does the Stock Market Overreact?, 40 J. Fin. 793, 799 (1985) (investor overreaction to unexpected and dramatic news "is asymmetric; it is much larger for losers than for winners."); De Bondt \& Thaler, Further Evidence on Investor Overreaction and Stock Market Seasonality, 42 J. FIN. 557 (1987) (same). There are at least two other possible explanations for why investors might react more strongly to bad news. First, bad news may be inherently more believable than good news because it would seein less likely that bad news has been fabricated. On the other hand, there are any number of reasons to fabricate bad news too. For example, inanageinent may wish to buy back the coinpany's shares at lower prices. However, the legal disincentives for misrepresentation are substantial. See Securities Act of 1933, 15 U.S.C. \$\$ 77k, 771 (1988). Second, the market may react more strongly to bad news because various rules and regulations inhibit the downward movenent of prices in normal circumstances. For example, it is illegal to sell a stock short when the most recent change in price was downward. See generally Macey, Mitcliell \& Netter, Restrictions on Short Sales: An Analysis of the Uptick Rule and Its Role in 
ing finding. A diversified investor ought to be indifferent to developments at a particular company since bad news at one will be offset by good news at another. That is, a diversified investor ought to be riskneutral with respect to company-specific risks. Thus, the fact that market prices react at all to company-specific news indicates that shareholders do not, in fact, behave as prevailing theory would suggest. On reflection, the idea that mvestors should not care about company-specific risk is clearly paradoxical. If investors did not care about companyspecific events, then stock prices would not move in reaction to thein. But the efficient market hypothesis, from which model investor behavior is derived, holds, in part, that all available information is absorbed almost instantaneously imto the price of each stock, as well as the market as a whole, by the interaction of competing traders. ${ }^{66}$

The paradox is to some extent illusory, however. The idea that a diversified investor is risk-neutral with respect to company-specific risks is not the same as the idea that the investor ignores such risk altogether. A risk-neutral investor is simply not risk-averse. Such an investor will adjust his or her opimion of the value of a company in proportion to the newly discovered risk or lack of it. Risk-neutrality only means that the investor will not overreact to the news. ${ }^{67}$

The fact that market prices react more strongly to negative news

View of the October 1987 Stock Market Crash, 74 CORNELL L. REv. 799 (1989). When the investors responding to negative news are institutional investors, the effect can be rather dramatic. See, e.g., Ingrassia, Polaroid Falls $22 \%$ on Negative News, Wall St. J., Oct. 16, 1990, at C7, col. 2 (22\% drop in price coincided with a lower-than-expected damage award in Polaroid's patent suit against Kodak); Steptoe, Riskier Ride: OTC Stocks Attract Institutional Investors, Become More Volatile, Wall St. J., July 26, 1989, at A1, col. 6 (lower-than-expected quarterly earnings of Price Co. resulted in a $14 \%$ drop in price, with $57 \%$ of the volume in blocks of 10,000 shares or more). Conversely, a company may inake strategic use of bad news by intentionally understating its earnings projections. If done properly, a company's stock will rise sharply in response to its announcement of higher-thanpredicted earnings. Cohen, "Low-Balling": How Some Companies Send Stocks Aloft, Wall St. J., May 6, 1991, at C1, col. 3.

66. The paradox is similar to the one in which an economist who spots a twenty-dollar bill lying on the sidewalk declines to pick it up, on the theory that if it were really there, someone else already would have taken it. For a general discussion of the efficiency paradox, sec Gilson \& Kraakman, supra note 7 , at 622-26.

67. Thus, the idea that the rational investor will ignore coinpany-specific news does not follow from the idea that a diversified investor is risk-neutral. Nevertheless, in order to deal with the contradiction implicit in shareholder indifference to company-specific news, it has been suggested that the rational investor will ignore newly discovered company-specific risk as long as the variation froin earlier expectation is within an expected range. In other words, the idea is that investors do or should ignore coinpany-specific risk, unless it is significant. But this solution itself destroys the proposition. At the very least, it means that investors inust determine whether the addition or subtraction of a particular risk rises to the level of significance required to trigger a reevaluation of the stock in question. Thus, the investor "eares" about risk in some sense of the word, and has spent resources in analyzing it. Moreover, and more to the point, to say that investors care about risks that rise to some level of signifieance is simply to affirm the idea that investors care about coinpanyspecific risk. 
than they do to positive news indicates that investors are risk-averse with respect to company-specific risks. The inescapable conclusion is that investors care about coinpany-specific risk. And, although the connection may not be immediately apparent, if investors do care about company-specific risk, then it almost certainly follows that stocks have downward-sloping demand. When investors atteinpt to assess companyspecific risk, they undoubtedly reach different conclusions about how much risk attends an investment in any given coinpany. If mvestors have heterogeneous opinions about coinpany-specific risk, then those who perceive less risk will be willing to invest at higher share prices than those who perceive more risk. Moreover, the fact that investors appear to be risk-averse with respect to company-specific risk suggests that the divergence of opinion is even greater than might be expected if shareholders were inerely risk-neutral.

To sum up the argument thus far, the irrelevance proposition suggests that investors are indifferent to dividends and should be unimpressed by a target company's undertaking to distribute a big dividend as a way of fending off a hostile bid. Yet the several arguments that have traditionally been advanced to disprove the irrelevance proposition are all unconvincing. The downward-sloping demand hypothesis, however, quite neatly explains why shareholders prefer dividends, and thus why a large, one-time distribution of cash may have the effect of discouraging a takeover. 68

II

\section{DisPaRATE VAluation}

Although few would deny that inost goods have downward-sloping demand, the idea that stocks do too is quite controversial. It is generally argued that a well-diversified investor who follows the dictates of the efficient market theory will be indifferent among various stocks. ${ }^{69}$ Such

68. One other possible reason why shareholders (and managers) may favor dividends is that a stock that pays dividends is much more difficult to sell short because the short-seller must pay the lender the dividend out of her own pocket, and once having sold the stock the borrower gets nothing from the declaring corporation. See Selling a Stock Short Is a Lot Riskier Than Buying, But the Way It Is Done Can Make It Very Profitable, Wall St. J., Sept. 5, 1985, at 25, col. I. Since there is reason to think that short selling inay sometimes evolve into downward inanipulation of a stock's price, see Rothart, Market Hardball: Aggressive Methods of Some Short Sellers Stir Critics to Cry Foul, Wall St. J., Sept. 5, 1985, at 1 , col. 6, there is reason to think that managers and shareholders would value dividend-paying stock, which is resistant to short sales.

69. See, eg., Cohen, Why Tender Offers? The Efficient Market Hypothesis, the Supply of Stock, and Signaling, 19 J. LEGAL STUD. 113, 131-32 (1990) (arguing that investors who believe that a company's stock is worth its market price will also believe that "each coinpany's stock is a substitute for inany others"); $c f$. Schwartz, The Fairness of Tender Offer Prices in Utilitarian Theory, $17 \mathrm{~J}$. LEGAL STUD. 165, 188-91 (stating that in the absence of a sentimental attachment to a particular stock, a shareholder derives the same benefit from owning a particular stock as owning its cash equivalent). The notion that sharelolders are indifferent aniong various stocks follows quite simply 
an investor is a rational price-taker who declines to waste time and effort atteinpting to pick undervalued stocks to buy, or overvalued stocks to sell. Moreover, since the rational investor diversifies, one stock is a pretty good substitute for any other. Purchases and sales of a particular stock should, therefore, have hittle if any effect on that stock's price, because there are always other stocks to buy and sell. Further, in the absence of inarket imperfections, the rational investor should choose to sell for any preimuin that might be offered. ${ }^{70}$ All of this has been taken to inean that the demand curve for stocks is horizontal or that the supply curve is vertical. ${ }^{71}$ In other words, a company may issue large amounts of new stock without depressing the stock price, and likewise an offeror may purchase virtually all of a coinpany's stock at a small premium over market without having to increase the offered price to obtain more and inore shares. In short, while there is evidence supporting the downwardsloping deinand hypothesis, and while virtually every other commodity is thought to have a downward-sloping demand curve, there are some good arguments for the level-deinand hypothesis in the context of stock.

Although one might not bother to elaborate in the case of commodities such as pork bellies or soybeans, the idea that stocks have downward-sloping deinand requires explanation because the behavior of rational shareholders would secm to result in level demand. There are, in fact, at least two good explanations. The first is that control has value. Shares are inore valuable to a shareholder who has control in a company than to one without such control. The second is that, even among noncontrolling shareholders, some imvestors are inore fully diversified than

from the efficient-market hypothesis and portfolio theory. That is, because the market price for a share of stock is the best guess as to its value, and because shareholders can eliminate companyspecific risk by investing in a portfolio of shares, it follows that nothing about a particular share of stock should matter much in making an imvestment decision. In any case, commentators have argued that for such reasons shareholders will likely tender for any premium, and that any effort by management to buy out its shareholders is suspect.

70. Professor Schwartz has argued that shareholders faced with a tender offer or other takeover bid behave much the same as they do in an ordinary market: they become price-takers because they do not know how the other shareholders will react. See Bebchuk, The Sole Owner Standard for Takeover Policy, 17 J. LEgAL STUD. 197, 198, 221-26 (1988) (calling for a higher regulatory standard to protect shareholders against such coercion); Schwartz, supra notc 69, at 179 83 (shareholders may be coerced into selling during a tender offer because they do not know what the other shareholders will do); Schwartz, The Sole Owner Standard Reviewed, 17 J. LEGAL STUD. 231, 232-33 (1988) (responding to Bebchuck). Indeed, many shareholders do sell in the open market to arbitrageurs during a bid instead of tendering the shares themselves, thereby avoiding the risk that they may tender too soon or too late, or that the bid may fail. See Federal Tender Offer Law, supra note 12, at 716 ("arbitragers often purchase shares froin skittish shareholders during the pendency of a tender offer").

71. For example, Professor Kraakman contrasts "downward sloping deinand curves for equity," implied by heterogeneous demand, with "the horizontal demand curves predicted by common forms of the efficient capital markets hypothesis." Kraakman, supra notc 4, at 899 n.25; see also Gilson \& Kraakman, supra note 7, at 570 \& n.67 (presenting evidence of horizontal demand). 
others. Clearly there is no excuse for the failure of a purely passive investor to diversify. However, it is not necessarily irrational to opt for less than coinplete diversification. There is every reason to believe that, even among purely passive shareholders, opinions about the value of any given company may legitimately differ. Therefore, an investor may decide not to diversify completely, choosing instead to consider some companyspecific risks in making investment decisions.

\section{A. The Value of Control}

The owner of control is privileged within broad limits to run the company as she sees fit. ${ }^{72}$ The controlling shareholder thus faces less risk because there is no chance that management will ever make a disagreeable decision. Other things being equal, less risk means that the same investment is worth more. ${ }^{73}$ Moreover, the freedom of a controlling shareholder to make self-serving choices for the company within broad legal limits creates some additional risk for noncontrolling shareholders, inasmuch as policies may turn out to be other than those they might have preferred. In short, a controlling shareholder's shares are by definition worth more than a noncontrolling shareholder's shares. To put it starkly, some level of looting is to be expected and tolerated. No one would buy control of a company unless control was worth something over and above the value of the shares themselves as passive financial claims agaimst the wealth of the company. Yet by definition any such excess value is denied to the remaining shareholders.

To some extent this argument apphies to all large shareholders who are in a position to affect the company's policies. Only a large shareholder has any mcentive to monitor management. ${ }^{74}$ The fewer shares one owns, the less one has to gain by keeping a close watch on management behavior, simce most of the benefits of monitoring will be captured by others who own inore shares. But even the larger shareholder, who niay have a sufficient interest to make monitoring worthwhile, will realize that monitoring efforts inure to the benefit of other shareholders as well, and will seek to capture part of that benefit by whatever favored treatment may be had. And rightfully so-monitors deserve to be paid like any other provider of services. ${ }^{75}$ Moreover, even if a monitor does

72. See, e.g., Sinclair Oil Corp. v. Levien, 280 A.2d 717 (Del. 1971) (a parent-subsidiary transaction without self-dealing by the parent is evaluated by the lower business judgment standard rather than the higher intrinsic-fairness standard).

73. See generally W. KLEIN \& J. COFFEE, supra note 21, at 189-98 (discussing expected return, risk, yield, risk premium, risk aversion, and volatility risk).

74. For a general discussion of monitoring by shareholders, see Levmore, Monitors and Freeriders in Commercial and Corporate Settings, 92 YALE L.J. 49, $59-75$ (1982).

75. See id. (describing incentives to monitor and rewards for performance); see also Principles of Corporate Governance: ANALysis and Recommendations 11-16 (Tent. 
not seek to be paid specially, the controlling shareholder will likely make a point of seeking to please any shareholder who is in a position to monitor. Thus, large blocks of stock that carry such perquisites tend to sell for more than smaller blocks.

The idea that control has value is strongly supported by the fact that controlling shareholders tend to be less well diversified than other investors. ${ }^{76}$ There are two fundamentally different reasons why investors invest: passive financial return, and financial return in connection with active management. The passive shareholder operating in an efficient market is a rational price-taker who considers it a waste of time and money to try to outguess the market. This is so not only because the market cannot consistently be beaten, but also because a diversified portfoho of investments, selected on the basis of offsetting risks rather than on predictions as to which coinpanies will perform best, minimizes the investor's overall risk.

The logic of diversification does not apply, however, to controlling shareholders, to those seeking control, or even to arbitrageurs who effectively broker the sale of control. The manager-investor is vitally interested in the fortunes of the subject company precisely because she is actively involved in its management. Moreover, the manager-mvestor often cannot diversify. In the first place, one would need to be fabulously wealthy to form a balanced, diversified portfoho, given the large financial investment required for the controlled coinpany alone. Second, and more important, much of a manager's investment is in the form of human capital such as knowledge, skills, contacts, and other intangibles that are not easily transferable. Fimally, the manager may have agreed, precisely for the passive shareholders' benefit, to forgo current coinpensation as a way of bonding performance, thus accumulating a still greater undiversified investment in the form of deferred compensation.

At first blush the inability of manager-investors to diversify suggests that their investments ought to be less valuable than those of diversified investors. That clearly cannot be the case, however, or no one would invest in control. Thus, it inust be that controlling shareholders tend to value their companies much more highly than do passive investors since

Draft No. 8, 1988) (discussing derivative suits and reasons for compensating successful plaintiffs); Booth, The Promise Of State Takeover Statutes, 86 Mrch. L. REv. 1635, 1643 (1988) (noting that shareholders benefit from two-tier tender offers).

76. See Coffee, supra note 8, at 16-24 (noting the greater diversifieation of shareholders as compared to managers). 
the value seen in the company must at least compensate the controlling shareholder for the additional risk taken by forgoing diversification.

\section{B. The Value of Diversification}

To explain why the demand for stock is downward-slopmg, it is not enough to show how opinions about a stock's value may differ between controlling and non-controlling shareholders-although certainly such differences of opinion would account for takeover premiums. Much of the evidence suggesting that stocks have a downward-sloping demand curve involves the way shareholders at the margin react to events such as new issues of stock or bad news. Why do opinions differ among these purely passive investors who have no interest in control? The differing opinions that such investors appear to have about the value of their investinents suggest either that such investors are not as well diversified as they should be, or that they behave under some circumstances as if they are less well diversified than they are.

In all likelihood both explanations contain an element of truth. It may be that the market is made up of both modestly diversified investors and coinpletely diversified or "indexed" investors. ${ }^{77}$ For most investors, the only way to achieve full diversification is by investing in a mutual fund. But, as one would expect with any valuable product, mutual funds charge for their services. All funds pay advisory fees and brokerage coinmissions at the fund level that reduce investor return; soine charge sales and redemption fees; and some fund advisers charge promotion and distribution expenses to the fund. ${ }^{78}$ Thus, for the investor who is in a position to hold a portfoho of, say, thirty stocks, the question becomes whether the marginal reduction in risk that comes with investing in a inutual fund is worth the inarginal reduction in return. It is not immedi-

77. It is unclear how much diversification is enough. Although an investor must hold something between 200 and 300 different issues to eliminate all company-specific risk, a portfolio with as few as 16 to 32 issues will eliminate $90 \%$ to $95 \%$ of such risk. See J. LORIE, P. DODD \& M. KIMPTON, supra note 3, at 21-24 (showing the relative dispersion of risk over a range of portfolio sizes); Langbein \& Posner, Market Funds and Trust-Investment Law, 1976 AM. B. FouND. RES. J. 1,11 (portfolio of 32 stocks is 95\% correlated with the S\&P 500); Bines, Modern Portfolio Theory and Investment Management Law: Refinement of Legal Doctrine, 76 ColuM. L. REV. 721, 795 (1976) (portfolio of 50 stocks may still differ from market return by four percent a year); Pozen, Money Managers and Securities Research, 51 N.Y.U. L. REV. 923, 951 (1976) (most commentators recommend portfolios of 40 to 50 stocks); see also Note, Broker Investment Recommendations and the Efficient Capital Market Hypothesis: A Proposed Cautionary Legend, 29 STAN. L. REV. 1077, 1096-99 (1977) (authored by John M. Salmanowitz) (metlrods of calculating desirable diversification); Note, The Efficient Capital Market Hypothesis, Economic Theory and the Regulation of the Securities Industry, 29 STAN. L. REV. 1031, 1037 n.29 (1977) (authored by Christopher Paul Saari) (describing formulas for calculating risk and return).

78. See Investment Company Act of 1940, 17 C.F.R. $\$ 270.12 b-1$ (1990) (requiring written plan describing allowable distribution expenditures by investment companies, with shareholder approval needed for material increases). 
ately clear that it is. ${ }^{79}$ Investors who quite rationally choose to manage their own portfolios are in a very different position from the hypothetical rational and fully diversified investors who are the foil for much current academic work. Unlike the "fully diversified investor," the inodestly diversified investor is capable of following the coinpanies in her portfolio. Some stock picking inay, therefore, be perfectly justifiable. After all, diversification is a two-way street: a well-diversified investor is largely free to play her lunclies without fear that guessing wrong will lead to a major loss. The same is true of the decision to tender or sell in the open inarket.

Moreover, if inodestly diversified investors are more active traders than fully diversified investors, as seems likely, it follows that inarket prices will inore strongly reflect the beliefs of modestly diversified investors. In other words, it may be that inarket prices are effectively set by modestly diversified and therefore somewhat risk-averse investors. These risk-averse investors are likely to respond inore strongly to bad news than to good news. However, existing investors who are moved by bad news to sell must sell to imvestors who were reluctant to buy at the old price, and who inay be even more reluctant after disclosure of the bad news. 80

79. A recent study by the SEC indicates that returns from funds whose advisers are allowed to charge promotion and distribution expenses to the fund (12b-1 funds) are as much as two to three percent lower than those which do not make such charges to the fund. Gould, The 12b-1 Disadvantage, N.Y. Tunes, July 15, 1990, § 3 (Money), at 14, col. 1; see also Winslow \& Anderson, A Model for Determining the Excessive Trading Element in Chuming Claims, 68 N.C.L. REv. 327 (1990) (proposing a comparison of the frequency of trading by mutual funds under the assumption that mutual funds experience optimal turnover rates).

Stock brokers are fairly well attuned to the trade-offs between the benefits of added diversification and the additional costs involved. During my involvement in one recent case, the broker told me that he had recommended that his eustomer open a margin account. By borrowing, the customer would be able to diversify to a much greater extent, the advantages of which would more than offset the interest payable on the margin loan.

Judge Posner argues that full diversification is well worth the cost. See R. POSNER, supra note 10 , at 405-10. His argument appears to be seriously flawed, however, in that he equates percentage reductions in risk with percentage reductions in return. Thus, the fact that one may still assume, say, $5 \%$ of the avoidable risk with a modestly diversified portfolio does not mean that an expected return of $10 \%$ will vary between $5 \%$ and $15 \%$. Assuming that there is a direet relationship between risk and return, which is far from clear, the expected variation on a portfoho with an expected return of $10 \%$ would be plus or minus $0.5 \%$. That is, one would expect to see returns as low as $9.5 \%$ and as high as $10.5 \%$. Moreover, diversification depends on more than the number of stocks in one's portfolio. It also depends on the relative market capitalization of the stocks that one picks. A portfolio of 30 stocks made up of very large companies would thus carry far less risk than a 30-stock portfolio made up of very small companies. One need only compare the movements of thic Dow Jones Industrials, which consist of a mere 35 stocks, with the $\$ \& P 500$ to see that there is hardly ever a significant difference betwcen the two.

80. One other reason why investors might hold different opinions about value is taxes. If investors are in different businesses or tax brackets, if they have offsetting losses, or if they have different bases in their stock, they may have different preferences for sale and different reservation prices. 
Advocates of the level demand curve support their hypothesis with the observation that shareholders do not react to the divergence between what the market says a company's stock is worth and what its managers say the stock is worth. Citing the efficient market for the proposition that there is one best estimate of the value of a company under incumbent management, commentators of very different leanings have suggested that claims by managers that the company is undervalued (and therefore an appropriate candidate to be taken private in a management buyout) or that the company is really worth more than some suitor is offering (and that therefore a tender offer must be resisted) are unworthy of behief. ${ }^{81}$ Professors Easterbrook and Fischel have argued in effect that shareholder demand curves must be flat, or "perfectly elastic," because if shareholders had varying opimions of the value of the same share of stock, those who held higher values would buy from those who held lower values, perhaps even if they had to borrow to do so. ${ }^{82}$ It might also be argued that if any investors honestly beheve a stock is undervalued, they would be willing to borrow to buy it, and that as a result the price would be driven up to reflect their beliefs.

The value of diversification provides two answers to this argument. First, rational sharelıolders value diversification and will not sacrifice it under ordinary circumstances. Even if they genuinely believe that a particular stock is undervalued in the market, they will not act on that belief and buy the stock beyond the point that the cost of decreasing diversification exceeds the gam of holding the undervalued stock. ${ }^{83}$ Clearly, this is true of the fully diversified investor-mieed it would seem to be true by definition. Furtliermore, there is no reason to beheve that it is not true with respect to the modestly diversified investor. Agam, the choice of the latter to manage his or her own portfoho is not irrational. To the contrary, to forgo a marginal amount of diversification rather than pay for it is a perfectly rational choice. There is no reason to ascribe to such an investor the tendency to engage in irrational stock-picking. It could even

81. See Carney, Controlling Management Opportunism in the Market for Corporate Control: An Agency Cost Model, 1988 WIS. L. REv. 385, 393 \& $\mathrm{n.26}$ (arguing that information needed to evaluate a firm's prospects may be masked by "strategic posturing"); Gordon \& Kornhauser, supra note 9, at 824 (suggesting that management's credibility is undermined by self-interest); $c f$. Oesterle, Target Managers as Negotiating Agents for Target Shareholders in Tender Offers: A Reply to the Passivity Thesis, 71 CORNELL L. REv. 53, $70-73$ (concluding that misbehavior by target managers facing a tender offer is neither "so frequent nor so difficult to penalize effectively that the judiciary ... cannot control it").

82. See Easterbrook \& Fischel, supra note 5, at 1165-68. It bears noting that this argunnent for the irrelevance of shareholder demand itself assumes that shareholder demand would operate to eliminate divergent opinions abont the stock in question.

83. See Schwartz, supra note 69, at 190-91 (explaining how the transaction cost of replacing stock in order to maintain the desired level of diversity reduces the value of a tender offer). On the other hand, the investor might consider going into the arbitrage busmess. 
be argued that such an investor has deinonstrated a bit more rationality than inany mutual fund imvestors, who overlook not only the hidden fees but also the disclosed ones.

Second, the decision to sell one's stock in the event of a tender offer stands on a very different footing froin the decision to buy up a supposedly undervalued stock. When a tender offer or other bid is being made for the whole coinpany, target shareholders know that they are negotiating with a bidder who seeks their shares as a means to gain control, and not as a passive financial investment. In other words, they are dealing with soineone who does not value diversification in the saine way they do, and the situation is ripe for capturing soine of the bidder's perceived gain. ${ }^{84}$

Moreover, there is no sacrifice of diversification by failing to tender. While it is easy to see why a shareholder would not act on the behef that a particular coinpany is overvalued or undervalued if it meant sacrificing diversification, that argument misses the mark in the context of a tender offer. In a tender offer, the shareholder who starts out with an adequately diversified portfohio of fifteen to thirty issues will have no more than $3 \%$ to $7 \%$ of her holdings in any particular stock. The decision the investor faces during a tender offer is. whether to sell or hold that portion of the portfoho, not whether to put all of her eggs into one basket.

Professors Gilson and Kraakman have asked whether there is "an important distinction between arbitrage within the securities inarket and arbitrage across the securities and asset markets" that might help to explain how discounts arise. ${ }^{85}$ The fact that bidders and investors place different values on diversification seeins to answer their question. The evidence that diversification in the real asset nnarket is value decreasing rather than value increasing is considerable. ${ }^{86}$ Indeed, although the idea

84. Professor Cohen has offered a somewhat similar analysis in explaining the existence of tender offers. The problem he sees is that a bidder will find it diffieult to buy enough shares on the open market to gain control, because relatively few investors are ready to sell at any given moment, and because the rapidly inereasing premiums that would need to be offered to climb the almost vertical supply curve would make the offer prohibitively expensive. Thus, tender offers operate as a signal to investors, who would not otherwise be in the market, that a buyer for the assets has emerged. In other words, they smoke out the investors who would otherwise prefer to hive in ignorance of the underlying value of the firm and continue to take the price offered by the ordinary trading market. As Professor Cohen sees it, a tender offer has the effect of turning the almost vertical supply curve into an almost horizontal one. Cohen, supra note 69, at 126-32.

85. R. Gilson \& R. KRAakman, The LAW and Finance of CoRporate acquisitions 57 (Supp. 1989) (describing the market version of the discount hypothesis).

86. See, e.g., Note, The Conflict Between Managers and Shareholders in Diversifying Acquisitions: A Portfolio Theory Approach, 88 Y ALE L.J. 1238 (1979) (recommending stricter judicial scrutiny of acquisitions to protect shareholders' interests); Jarrell, For a Higher Share Price, Focus Your Business, Wall St. J., May 13, 1991, at A14, col. 3 (arguing that stock performance is better for focused rather than diversified corporations); Melloan, Why FMC Let Shareholders Do the Diversifying, Wall St. J., Aug. 16, 1988, at 29, col. 3 (distribution of capital to shareholders improved 
behind many conglomerate mergers was that the same principles of diversification apphied to real assets and financial assets, diversification at the company level has been blamed for much of the recently abated takeover wave. ${ }^{87}$ In hindsight, the flaw in the logic of conglomerate mergers seems evident. After all, why should investors pay anything extra for a collection of companies chosen by managenent, when the investor could concoct any combination of busimesses virtually instantaneously and at minimal cost by composing a portfoho of stoek in selected companies? ${ }^{88}$

At first blush, these phenomena seem inore consistent with, and thus supportive of, the mismvestment hypothesis than with the market hypothesis. On the other hand, it may simply be that as a company's management makes more elaborate choices for its investors, there will naturally be fewer investors who find the precise choices inade to their liking. In the end, the point is the same as that made in connection with dividends. When it is easy for the shareholder to achieve the same effect as a corporate-level transaction, the shareholder will be indifferent to whether the corporation nndertakes it-unless, of course, other costs, such as transaction costs, make it more expensive to achieve the same result in one or the other way. ${ }^{89}$ Since diversification can achieve virtually any investment mix at the portfolio level, theory predicts that the shareholder should care little about diversification at the company level.

firm's economic outlook); Colvin, The Bigness Cult's Grip on Beatrice Foods, ForTuNE, Sept. 20, 1982, at 122-23 (ten-year average rate of return for extensively diversified Beatrice Foods was $2.5 \%$, before inflation).

87. See Porter, From Competitive Advantage to Corporate Strategy, HaRv. Bus. Rev., MayJune 1987, at 43, 43-52 (diversification mistakes make companies vulnerable to corporate raiders).

88. This may also explain why closed-end mutual funds routinely sell at a discount from net asset value. See Kraakman, supra note 4, at 902-08 (exploring reasons for this practice). The discount at which closed-end funds trade is particularly remarkable, given that the value of underlying assets is readily ascertainable. At least oue study has concluded that the reason why closed-end funds trade at a discount from the underlying assets is because investors hold heterogeneous views about the value of the fund. Thompson, The Information Content of Discounts and Premiums on Closed-End Fund Shares, 6 J. FIN. ECON. 151, 181 (1978) (describing variations in shareholder preferences about timing, magnitude, and tax status of dividends). In other words, demand for such funds slopes downward. Again, the counection between heterogeneous opinions as to value and downward-sloping demand is fairly straightforward. Only a very small number of investors will completely agree at any given time with the counposition of the portfolio. The reason for the diseount may be the same as the reason for deconglomeration: namely, that investors do not value prepackaged diversification. Whatever the reason for the discount suffered by closed-end funds, the SEC has recently proposed that prospectnses for them carry a warning that the price of the fund is likely to fall in the aftermarket. Registration Form for Closed-End Management Investınent Coinpaines, Securities Act Release No. 6,842, [1989 Transfer Binder] Fed. Sec. L. Rep. (CCH) If 84,433, at 80,331 (July 28, 1989).

89. See supra text aecoinpanying notes 19-24. This suggests several further empirical inquiries and lines of analysis. For example, is the per-share cost of the typical merger more than the cost of commissions for an investor who effects her own inerger by adding the company to her portfolio? Are junk bonds in effect a cheaper way of buying on margin? Or does buying on margin affect the riskiness of the stock bought on margin? Is it possible that fee-seeking investment bankers were the prime movers behind conglomerate mergers, and if so, what should be done about thein? 
Finally, the arguinent that a well-diversified, rational shareholder who believes in the efficient market should therefore sell for any preinium simply proves too inuch. It is well known that a tender offer causes the price of the stock in the target to rise, often to a level that is as high or higher than the offered price. A well-diversified investor who follows a rational buy-and-hold strategy would, according to sucli logic, seldom, if ever, tender. But the market price will rise ouly because some investors will in fact compare the price offered with their own reservation price. No doubt, too, many investors will seek out information about what other investors are doing, causing the market to leap suddeuly to a new price to reflect the offer adjusted by the effective consensus concerning the likelihood of success and competing offers. But the speed with which the inarket works does not imply that it inysteriously divines a new price utterly without the help of the interplay of supply and deinand as determined by the differing opimions of investors. ${ }^{90}$

There are few reasons for even well-diversified investors to reinain indifferent when a stock they hold is in play. The logic of the efficient market and diversification does not apply with any force to the bidders who buy whole companies. Clearly, the bidder would not be bidding unless she believed that the target was undervalued. Why then should an investor (even one who is ordinarily a passive price-taker) sell shares for a minimal preımum? In short, when there is a bidder or potential bidder lurking about who is interested in managing or liquidating the target coinpany, the logic of the efficient market and diversification no longer applies, even for the passive investor who must decide whether to sell out or hold out. Rather, in such situations investors may act, quite ration-

90. How does the market know when supply has been reduced? Do market forces somehow convey this information when, for example, traders discover that it takes more phone calls to find a seller? Or do traders depend on overt disclosures emanating from the company or a major investor who is required to disclose that additional supply has been or will be injected into the inarket? If the latter, it could be argued that the price effect of sales and repurchases is likely to be a result of new information implicit in such moves by the company and insiders. But, as with the evidence relating to secondary offerings, even if such moves have informational value, there is no reason to think they do not also affect the equilibrium price by what might be called technical forces. One likely answer for how the market knows when supply is reduced is that specialists and market-makers pick up on imbalances in their long and short positions. Moreover, there is reason to believe that traders inomitor the activities of other traders, looking for indications of hidden value, and that some trades thus have an impact on the market far beyond the value of the shares in that trade alone. See W. Baumol, The StOck MARKeT AND Economic EFFiciency $51-53$ (1965) (traders react to conspicuous external signals in trying to anticipate one another's behavior), quoted in $\mathrm{V}$. BRUDNEY \& M. Chirelstein, supra note 19, at 128-30; Gilson \& Kraakman, supra note 7, at 572-79 (uninformed traders observe transactions of informed traders to gain information). Finally, traders and portfolio managers are reluctant to be seen performing less well than the competition, and therefore will tend to follow the lead of other influential traders and advisers even if they do not necessarily believe the others' information or strategies to be superior to tlieir own. See, e.g., Dorfman, "Window Dressing" Ritual Can Aid Small Investors, Wall St. J., Mar. 29, 1991, at C1, col. 5. 
ally, on the basis of differing opinions as to the value of a company's stock or the value believed to be perceived by the other party to the trade. When such situations arise, demand is no longer horizontal.

Thus, although it is tempting to assume that because the stock market is efficient there is a single correct or at least best-guess price for a stock, there is nothing imconsistent between the idea that the market is efficient in the sense that it cannot be beaten, and the idea that shareholders may hold different opinions as to the value of a particular stock. Again there is no reason why very different equilibrium prices would not be establislied for the same security at different levels of supply. But the clear implication of downward-sloping demand is that a company can be, and indeed ordinarily is, worth more than the market price of its stock tinies the number of sliares outstanding. ${ }^{91}$

\section{III \\ Other Evidence of Downward-Sloping Demand}

Numerous economic phenomena support the theory that stocks have downward-sloping demand curves. As already noted, the downward-sloping deinand liypothesis is directly supported by the fact that new issues of stock and block sales by existing investors tend to force stock prices down. The theory is further supported by the fact that investors appear to react more strongly to bad news thian they do to good news. One need not dig too deeply to find additional evidence.

\section{A. Share Repurchases}

It is well known that coinpaines often repurchase their own stock in order to support or increase the market price. ${ }^{92}$ This plienomenon is persuasive evidence of the downward-sloping deinand hypothesis: if the demand curve for stock were horizontal, such repurchases would not

91. The question remains, however, why arbitrage does not arise in anticipation of a takeover bid, thus erasing the discount before a bid can ever get going. That question, however, almost answers itself. Such arbitrage no doubt occurs to some extent. Indeed, it is quite common to hear that trading activity in a particular stock was prompted by takeover speculation. But if arbitrage eliminated discounts completely, the takeover bid would never arise. And if the arbitrageur did not have reason to believe that a bid would arise, there would be nothing to arbitrage.

92. See Kraakman, supra note 4, at $916-20$ (discussing equity conversions, especially recapitalizations, as takeover defenses); Palmer, Promises, Promises: Or What Happened to All Those Post-Crash Buybacks?, BARRoN's, Apr. 25, 1988, at 13; Wallace, Takeovers and Buybacks Propping Up Stock Prices, N.Y. Tunes, June 20, 1988, at D1, col. 1 (late city final ed.). Consider, for example, Sears' recently announced massive repurchase of stock (together with the sale of such notable assets as the Sears Tower) because of fears that its stock was too cheap and that it might become the target of a takeover attempt. See supra text accompanying note 17. For cmpirical evidence concerning the effect of repurchases on stock price, see generally Dann, Common Stock Repurchases: An Analysis of Returns to Bondholders and Stockholders, 9 J. Fin. EcoN. 113 (1981); Masulis, The Impact of Capital Structure Change on Firm Value: Some Estimates, 38 J. FIN. 107 (1983); Smith, Investment Banking and the Capital Acquisition Process, 15 J. FiN. EcoN. 3 (1986). 
have any tendency to raise the market price, nor would remaining shareholders enjoy any benefit. On the other hand, the downward-sloping demand hypothesis makes it easy to see how such price adjustments and shareholder benefits arise.

During the 1987 stock market crash, numerous compainies repurchased their own shares pursuant to existing and newly announced repurchase plans. The Securities and Exchange Commission (SEC) report on the crash indicates that during the week of October 19, 1987, there were 129 compaines ainong the S\&P 500 that repurchased shares, with the median company repurchasing almost $13 \%$ of its outstanding shares. ${ }^{93}$ Among repurchasing companies, share prices fell $17.5 \%$ during the first two days of the week compared with a fall of $19.6 \%$ for other coinpaines. ${ }^{94}$ For the entire week they fell $15 \%$ coinpared to $16.5 \%$ for other companies. ${ }^{95}$ When price changes are adjusted for the riskiness of individual stocks, the results are even more dranıatic. ${ }^{96}$ Moreover, the compamies that repurchased a larger percentage of outstanding shares saw their shares fall significantly less than those that repurchased smaller anrounts. ${ }^{97}$

It is unlikely that this price effect was a result of some signal coinmumcated to the market by the announcement of the repurchase progran. Ninety percent of the shares repurchased were repurchased by companies with existing repurchase programs, or by coinpamies that had announced their programs on an earlier day of the week. ${ }^{98}$ Typically, once the program is aunounced there is no announcement for individual repurchase transactions. ${ }^{99}$

Arguably, it is not entirely fair to count share repurchases as an additional example of downward-sloping demand because they are, after all, substantially equivalent to dividends. ${ }^{100}$ Sometimes repurchase programs are even announced in heu of regular dividends. ${ }^{101}$ In recognition of this similarity, state corporation law regulates the two transactions in a very similar manner; soine jurisdictions, in fact, draw no distinction between the two. ${ }^{102}$ Nevertheless, sliare repurchases are different from

93. See Div. of MKT. Reg., SEC, The October 1987 MARket Break 6-5 (1988).

94. Id.

95. Id.

96. Id. at 6-5, 6-6.

97. Id. at 6-6.

98. Id. at 6-4. At the beginning of the week, 101 companies had previously announced repurchase programs, and during the week 57 companies announced new or accelerated repurchase programs. Id.

99. Id. at 6-9 n.8.

100. See R. Clark, Corporate LAW 626-27 (1986).

101. See V. Brudney \& M. Chirelstein, supra note 19.

102. See, eg., REvised MOdel Business CORP. ACT $\S 6.40$ (Supp. 1989) (including purchases and redemptions in definition of distribution). 
dividends in that they are, by definition, not pro rata.

The downward-sloping demand hypothesis is the only logical explanation for the fact that repurchases tend to cause an increase in the market price of the subject stock. After all, only selling shareholders get the money. Thus, even if shareholders prefer dividends because they are concerned that manageinent will misinvest available cash, that hardly explains why repurchases of other shareholders' shares are viewed favorably by nonselling shareholders. The straightforward explanation would seein to be that the lowest-valuing shareholders have been eliminated and that the equilibrium price of the shares has worked its way up the demand curve. ${ }^{103}$

Remarkably, there has been little protestation that repurchase programs constitute inamipulation. No doubt the silence is due in part to the fact that corporate treasurers, who are sensitive to the charge of manipulation, deny that the reason for repurchases is to raise prices. Rather, they almost invariably claim that the reason is that the repurchases act as a signal to the market, or that the stock is underpriced and therefore a good investment. ${ }^{104}$ These explanations are at best thinly veiled. If the stock is a good investinent, whether for the company or anyone else, and the coinpany has the cash, presumably it will repurchase shares until the price reaches an acceptable level. The idea that the repurchase was not intended to raise the price would, as the saying goes, hardly stand up in court. Nevertheless, what protest there has been about repurchases has been based on the notion that repurchase programs inay be unfair to selling shareholders who might be more inclined to retain their shares if they knew that the issuing company was buying its own shares in the open market. ${ }^{105}$ It has thus been argued that repurchase programs should be well disclosed so as to give all shareholders the opportunity to make a rational choice to hold or sell. ${ }^{106}$ Yet if demand were horizontal, disclosure would be irrelevant because the repurchase would not be expected to have any effect.

103. Of course, it could be that the issuer's announcement that it stands ready to buy shares encourages investors to invest. But that in itself is nothing but an expression of the downwardsloping demand hypothesis insofar as the reason investors are more willing to invest is that they need not worry as much about future sales driving the price of the stock much below levels prevailing at the time of the announcement.

104. See Wansley, Lane \& Sarker, Management's Views on Share Repurchase and Tender Offer Premiums, 18 FIN. MGMT. 97 (1989); see also Cohen, Why Companies Buy Their Stock High, Then Sell Low, Wall St. J., July 15, 1991, at C1, col. 3.

105. See R. ClaRK, supra note 100, at 629 (arguing that stock repurchases may mislead shareholders into thinking that active trading is motivated by "favorable nonpublic information").

106. See Bradley \& Rosenzweig, Defensive Stock Repurchases, 99 HARV. L. REv. 1377, 1385-87 (1986) (arguing that stock repurchase programs should be required to proceed as self-tender offers under SEC rule 13e-4); see also V. BRUDNEY \& M. ChIRELSTEIN, supra note 19, at 476-84 (discussing generally the issues of manipulation, stabilization, and corporate repurchases). 
In 1982, the SEC responded to these concerns with a new rule, Rule 10b-18, which creates a safe harbor for issuer repurchases in the open market. ${ }^{107}$ The rule provides that an issuer repurchasing its own shares will not be deemed to be manipulating the market if four conditions are met. First, purchases, excluding block purchases, may not exceed $25 \%$ of the average daily volume in the company's shares. Second, purchases may not be made at the opening of the market or in the half hour before the close. Third, the price paid must be the market price. Fourth, all repurchases on any given day must be made through a single brokerdealer.

What is odd about Rule $10 b-18$ is what it does not say. It does not say that the repurchase plan must be disclosed. Of course, it may be that the plan must be disclosed for other reasons if its existence rises to the status of a material fact. But Rule $10 \mathrm{~b}-18$ provides that an issuer shall not be deeined to have violated either Section 9 or Rule $10 b-5$ solely by virtue of repurchases carried out according to the terms of Rule 10b-18. The rule is, thus, narrowly crafted to protect against the possibility that issuer repurchases might lead the market or create the appearance of more disinterested trading activity than actually exists.

Regulatory nonchalance about the manipulation apparently inherent in open-market share repurchases is quite consistent with the downward-sloping demand theory. If shareholders hold differing views of share prices, repurchases must be viewed very differently than if repurchases are primarily interesting to shareholders as a matter of information. If the former is the case, the issuer's taking advantage of such differences by reabsorbing the lower-priced shares, and thus raising the market pricc, is simply not the sane thing as manipulating shareholder opinion.

Although the vast majority of issuer repurchases are made in the normal course of trading, underwriters acting on behalf of an issuer sometines repurchase shares during an offering to support or "stabilize" the market price. The SEC has reacted to this practice by promulgating detailed rules about what an issuer or underwriter may do to stabilize the price of a stock during a new offering. ${ }^{108}$ In essence, an issuer or underwriter may purchase shares at a price less than or equal to the price at which they are being offered. ${ }^{109}$ This allows for stabilizing purchases that follow the market down but not up. ${ }^{110}$ Stabilization is allowed dur-

107. Sec. Exch. Act Rule 10b-18, 17 C.F.R. $§ 240.10 b-18$ (1990).

108. 17 C.F.R. $\$ \$ 240.10 b-6$ to -8 (1990); see T. HAZEN, THE LAW of SEcurities REGULATION 173-77 (1985) (explaining the SEC's regulations on price stabilization in the context of public offerings).

109. See 17 C.F.R. $\S 240.10 b-7(\mathrm{j})$.

110. 17 C.F.R. $\$ 240.10 b-7$ (c) ("No stabilizing bid or purchase shall be made except for the purpose of preventing or retarding a decline in the open market price of a security."). 
ing "fixed-price" offerings, ${ }^{11}$ but is completely forbidden in "at-the-market" offerings. ${ }^{112}$ However, because fixed-price offerings are the rule and at-the-1narket offerings are the exception, this limitation has hittle practical significance. ${ }^{113}$

If denand for stock were perfectly elastic, stabilization would be wholly unnecessary and, indeed, would not be worrisome. However, the number of regulations aimed at stabilization, ${ }^{114}$ and the scholarly criticisms pointing out the dangers of stabilization, ${ }^{115}$ behe such a sense of security, as does the fact that share repurchases do tend to inflate the price of the stock. ${ }^{116}$ The problein is that fixed-price offerings are utterly inconsistent with the reality of downward-sloping demand. As a result, stabilization is an evil needed to inake fixed-price offerings work. In other words, the practice of stabilization is tolerated because of fixedprice offerings, but fixed-price offerings are themselves a suspect institution.

\section{B. Initial Public Offerings}

Today, the stabilization problein seems to have taken care of itself, although the cure may be worse than the disease. The use of stabilization has diminished because underwriters have become more adept at selling out new issues quickly. ${ }^{117}$ There is, however, a sinister explanation for the efficiency of underwriters. Numerous studies have shown that stocks sold in initial public offerings (IPOs) frequently carry higher riskadjusted returns than other stocks. ${ }^{118}$ In other words, IPOs are system-

111. A "fixed-price" offering is one made at a simgle, predetermined price.

112. 17 C.F.R. $§ 240.10 \mathrm{~b}-7 \mathrm{~g}$ ) (1990) (explicit rule against any open-market purchases of stock by an issuer or underwriter during an at-the-market offering). An "at-the-market offering" is an offering for which there is no set price.

113. Indeed, as one leading text on securities regulation puts it, it is impossible to read the Securities Act of 1933 and not come to the conclusion that fixed-price offerings were what Congress had in mind. R. JeNNings \& H. Marsh, Securities Regulation: CASES AND Materiats 595 (6th ed. 1987). In any case, there can be little doubt that the securities industry is organized around the fixed-price offering. The standard operating procedure is for the underwriter to set a price for the shares, buy them wholesale from the issuer at an agreed discount, and resell them to the public at the full fixed price per share. Indeed, the National Association of Securities Dealers has a strict rule against reselling shares in a fixed-price offering at any price other than the stated fixed price. See Practices in Fixed Price Offerings, Securities Act Release No. 15,807, [1979 Transfer Bimder] Fed. Sec. L. Rep. (CCH) I 82,073, at 81,763-64 (May 9, 1979) [hereinafter Fixed Price Offerings]; In re National Association of Securities Dealers, Exchange Act Release No. 17,371, Fed. Sec. L. Rep. (CCH) If 82,705, at 83,871-73 (Dec. 12, 1980).

114. See supra note 108.

115. For example, Professor Stout characterizes stabilization as an artificial propping up of market price, and argues that it is mconsistent with the philosophical underpinnings of most of securities regulation-that efficiency slould be encouraged above all else. Stout, supra note 9 , at 664, n.265.

116. See supra notes $92-97$ and accompanying text.

117. See R. JENNINGS \& H. MARSH, supra note 113, at 601-02.

118. See Ibbotson, Price Performance of Common Stock New Issues, 2 J. Fin. Econ. 235 (1975) 
atically underpriced. One likely explanation for such underpricing is that underwriters are more concerned with selling out the issue quickly and avoiding the risk that market conditions may change than they are about getting top dollar for issuers. Thus, IPOs are priced below the anticipated equilibrium price in the aftermarket. ${ }^{119}$ Professors Gilson and Kraakman argue that underpricing is simply a way for underwriters to invest im their customer base. ${ }^{120}$ That is, the underwriter is able to place stock for issuers because it has a stable of investors and keeps thein happy by giving them bargains. But it is unclear why issuers are willing to have their stock sold for less than it is worth. Moreover, it is unclear why investors need a bonus at all, unless they are somehow coerced at other times to buy overpriced products. The most likely explanation for underpricing of IPOs is the downward-sloping deinand hypothesis. If indeed stocks have downward-sloping demand, then underwriters must price shares so as to sell to the lowest valumg investor.

Why then does the price later rise in the aftermarket? One explanation, proposed by Easterbrook and Fischel, is that higher-valuing shareholders buy from lower-valuing shareholders, and thus drive the price up. ${ }^{121}$ On the one hand, such aftermarket reallocation is consistent with the downward-sloping demand hypothesis. On the other hand, it ineans that underwriters consistently misjudge how low the price must be set in order to sell out the issuc. Thus, the downward-sloping demand hypothesis would seem to offer, at best, an incomplete explanation for underpricing of IPOs.

Another plausible explanation for the postoffermg price rise is that underwriters cannot be content with finding iust enough investors to buy the new issue. No doubt some investors will renege on their promises to buy-indeed, such promises are unenforceable under the Securities Act of 1933. It is illegal to sell securities before the registration statement has become final, at which time the price of a fixed-price offering has been set. ${ }^{122}$ As a result, it is far too dangerous froin the underwriter's point of view to assume that every customer who has indicated an interest in purchasing some shares will in fact do so. ${ }^{123}$

(examining the risk and performance of new issues offered from 1960-69); Ritter, The "Hot Issue" Market of 1980,57 J. Bus. 215, 215-16 (1984) (analyzing why high risk initial public offerings are underpriced).

119. Needless to say, investors are therefore quite anxious to be allotted a few shares, simce the price can be expected to rise immediately.

120. Gilson \& Kraakman, supra note 7, at 621 n.197.

121. See supra text accompanying note 82 .

122. Securities Act of 1933,15 U.S.C. $\$ 77$ e.

123. The underwriter generally assumes the risk of loss aceruing from an incompletely sold-out offering. See generally Fixed Price Offerings, supra note 113, at 81,756-59. Although the underwriter may retaliate in the future by not selling the next issue to an undependable customer, the costs are too high in each individual offering to depend on this as an effective enforcement tool. 
Through regulation, the SEC and the National Association of Securities Dealers (NASD) may have further exacerbated the problem of systematic underpricing. The Commission has worried itself more than once about IPOs, especially in so-called "hot issue" markets when investors appear ready and willing to buy vast quantities of risky stocks. Yet the SEC has never taken a firm position on what causes hot issues and how to fix the problem. The price run-up in the aftermarket is thought to be caused by a restriction of the supply of shares actually sold to something less than the number stated in the prospectus. The unsold shares, which may have been allotted to various insiders, then flood the market at the higher aftermarket price, which promptly collapses, but only after the msiders have been able to sell their shares. ${ }^{124}$ The SEC has warned that such practices may constitute manipulation and that failure to sell the issue to bona fide investors may render the prospectus and registration statement false and misleading. ${ }^{125}$ For its part, the NASD has adopted rules that limit to $10 \%$ of the issue the anrount of stock an underwriter may retain as compensation for the underwriting. ${ }^{126}$

The SEC's hot issue scenario is premised on downward-sloping demand since otherwise the supply of stock would have no effect on market price. It is therefore curious that neither the SEC nor the NASD has suggested that fixed-price offerings themselves might have something to do with making hot issues hot. The reason may be that fixed-price offerings are more profitable for underwriters. ${ }^{127}$ After all, as the name suggests, they are a form of price fixing.

For whatever reason, the SEC and the NASD have ignored the obvious solution of encouraging at-the-market offermgs. Instead, both apparently beheve that assuring as wide a distribution as possible of newly issued shares will avoid the potential for a flood of sell orders after

124. The practice of "flipping" new issues may also contribute to the aftermarket price drop. Lowenstein \& Donnelly, Hot IPOs Best Played by Those With Cool Heads, Wall St. J., May 10, 1991, at Cl, col 3; see also Lowenstein, Caution Flags Rise in New-Stock Boom, Wall St. J., June 27, 1991, at $\mathrm{Cl}$, col. 4.

125. See In re Shearson, Hammill \& Co., 42 S.E.C. 811 , 821 (1965) (citing 17 C.F.R. \$ 240.10b6); The Obligations of Underwriters, Brokers and Dealers in Distributing and Trading Securities, Particularly of New Higlı Risk Ventures, Exchange Act Release No. 5,725, [1972 Transfer Binder] Fed. Sec. L. Rep. (CCH) \ 4,506B, at 4060-61 (July 26, 1972) [hereinafter Hot Issue Release]; Preliminary Report on Practices in Distribution of Hot Issues, Securities Act Release No. 4,150, [1959 Transfer Binder] Fed. Sec. L. Rep. (CCH) ๆ 76,671 (Oct. 23, 1959); see, e.g., Hagedorn \& Newman, Highflying Broker: Blair New Issues Defy Gravity-With Help from J. Morton Davis, Wall St. J., May 6, 1991, at A1, col. 6. (reporting an informal investigation by the SEC of a particularly successful IPO underwriter in response to allegations of manipulation). See generally T. HAZEN, supra note 108, at 177-79 (generally discussing "hot issues").

126. See "Free Riding and Withholding," N.A.S.D. Manual (CCH) I 2151, at 2046 (Oct. 1987).

127. See Banoff, supra note 45 , at 146 (explaining that underwriters of fixed-price offerings are coinpensated for the risk that the issue will not sell out). 
the price rises in the aftermarket. ${ }^{128}$ In fact, distributing offered shares too broadly may be part of the problem.

In the first place, those closest to the offering presumably know the most about the offering and the company. Thus, it seems likely that insiders such as employees of the underwriting firm and of the various broker-dealers who make up the underwriting and selling groups will count among the highest-valuing imvestors. This is not to suggest they have inside information, however. Rather, because they know relatively more about the issuer, insiders are able to avoid soine of the risk that the public perceives in newly offered shares. Thus, insiders would be expected to value the offered shares a bit higher than other investors.

Second, a broader offering, imvolving many smaller purchasers, eliminates the worry that a larger purchaser who chooses to resell will be deemed an underwriter. If this happens, the offer will be considered still underway during these later sales, even though the issuer and the official underwriters consider it completed. To avoid this result, underwriters may prefer to sell new issues to more custoiners for a lower price, than to the smaller number who would pay top dollar. If so, it is only to be expected that the highest-valuing investors will turn to the market for the additional shares they want, naturally driving the price up.

Professors Chalk and Peavy have offered another intriguing explanation for the underpricing of IPOs that also draws on the possibility that stocks have downward-sloping demand. They argue that underpricing arises because, despite outward appearances, IPOs are sold in discriminatory rather than competitive auctions. ${ }^{129}$ Underwriters typically establish a price for an offermg by polling or "circling" customers to determine investor interest before undertaking to prepare and file a registration statement with the SEC. Then, between the filing date and the effective date of the registration statement, the underwriter promotes the offering by distributing a preliminary prospectus, which describes the company and the reasons for the offering but does not set a price. While an investor who indicates a willingness to buy at a particular price during the preeffective period is not legally bound to do so, the investor is practically bound: if she backs out, the underwriter is unlikely to make future offerings available to her. Thus, the investor must carefully assess the merits of the offering without the help of an active market that continuously sets an equilibrium price for the shares. From the investor's point of view, the worry is that she will pay too much relative to the aftermarket price. Thus, each investor's bid will be discounted to coin-

128. See Hot Issue Release, supra note 125, at 4159-61; see also "Free Riding and Withholding," supra note 126.

129. Chalk \& Peavy, Understanding the Pricing of Initial Public Offerings, 8 RES. IN FIN. 203, 215-17 (1990). 
pensate for the added risk of overpaying. When the shares are finally issued and begin to trade, however, that aspect of the risk is eliminated and the price naturally rises.

This explanation is especially interesting because it blends the downward-sloping demand hypothesis with the level-demand hypothesis. The essential reason for underpricing is that a discriminatory or stair-step auction, in which each investor must establish a reservation price in isolation, is transformed into a competitive auction, in which everyone has the benefit of knowing the latest trade or at least a current quote. Ultimately it may be that the episodic transformation of one sort of market into another will allow the downward-sloping demand hypothesis to be reconciled with the level-demand hypothesis.

If indeed downward-sloping demand explains the behavior of the market in connection with the issuing of securities, and if fixed-price offerings allow underwriters to capture bigger profits, then presumably issuers are anxious to capture as much of the nnderpricing surplus as possible. There are signs that issuers have taken steps to do just that. "Dutch auctions" have grown in popularity over the last few years, both in connection with new issues of securities and in connection with repurchases. In a Dutch auction, the issuer sells first to the highest bidder, second to the next highest bidder, and so on until the issue is sold out. ${ }^{130}$ The technique has been used in connection with the sale of Umited States Treasury securities for many years, ${ }^{131}$ and has also recently arisen in connection with repurchases of both corporate stock and debt. ${ }^{132}$

\section{Tender Offers}

While the large premiums paid in tender offers are probably the inost drainatic evidence of the downward-sloping demand hypothesis, tender offers provide other kinds of evidence supporting the hypothesis. For exainple, the more shares one seeks in a tender offer, the more one

130. See Banoff, supra note 45 , at 147 (reviewing the procedures involved in the "Dutch auction"). See generally Note, supra note 45, at 1384-89 (explaining different types of auctions).

131. In the case of Treasury securities, the bids are sealed and one may opt to purchase in the so-called competitive auction whereby a certain percentage-typically about $25 \%$ - of the securities are sold at a fixed price established by reference to the Dutch-auction price. For a discussion of government securities auctions in connection with the recently breaking scandal at Salonon Brothers, see Macey, Don't Blame Salomon, Blame the Regulators, Wall St. J., Aug. 19, 1991, at A8, col. 3; Friedman, How to Sell Government Securities, Wall St. J., Aug. 28, 1991, at A8, col. 3.

132. These have been dubbed "blue light specials" after the short-term promotions at discount department stores. Whether the name is ineant to convey some sense of the quality of the securities being repurchased is unclear, though it has often been nsed in offers to repurchase stock with junk bonds. There are, however, other motivations for using a Dutch auction or variable price range in connection with a repurchase of stock. One is that by not setting a firm price, the issuer avoids indicating to potential bidders that the company might be bought at that price. See, e.g., Landro, CBS Inc. Is Said to Be Weighing Stock Buy-Back, Wall St. J., Nov. 29, 1990, at A3, col. 1. 
must pay per share. Indeed, it has been establislied empirically that tender offers for larger percentages of sliares carry larger premiums. ${ }^{133}$ This fact lias been attributed to the coercive effect that partial tender offers liave on target sliareholders, causing them to tender for a smaller premium than they would otlierwise demand. ${ }^{134}$ This phenomenon is also consistent witl downward-sloping demand.

In connection with bids for any or all of the sliares of a target coinpany, it is sometimes necessary to increase the offer in order to mduce sufficient tenders. ${ }^{135}$ While some of these price increases are clearly attributable to the emergence of a competing bid, others occur in the absence of such a bid. ${ }^{136}$ of course, it could be argued that the reluctance of shareliolders to tender is attributable to the expectation that another bid will arise. However, this is just another way of saying that many shareholders believe the offer is too low and that other bidders will appear. In otler words, it proves the point: people may have different opmions about the value of a sliare of stock.

Management buyouts provide furtlier food for thouglit in connection with downward-sloping demand. The downward-sloping demand hypothesis suggests that premiums slould be smaller in management buyouts than in third-party takeovers. During a manageinent buyout, it is presumably the higliest-valuing sliareliolders-current managementthat are purcliasing the company. Because manageinent does not need to buy its own shares, the downward-sloping demand hypotliesis suggests that it slould not need to offer as high a price to complete the buyout. In practice, lowever, premiums in manageinent buyouts appear to be as large as premiums in third-party offers. ${ }^{137}$ This inay be because inanage-

133. See Office of the Chief Economist, SEC, The Economics of Any-or-All, Partial, and TwoTier Tender Offers, 24 (April 19, 1985); SEC, The Economics of Partial and Two-Tier TENDER OFFERS, 49 Fed. Reg. 26,751 (1984).

134. Booth, supra note 75 , at $1640-43$.

135. See, e.g., Hanson Trust PLC v. SCM Corp., 774 F.2d. 47, 50-51 (2d Cir. 1985) (in bidding contest for control, bidder first offered $\$ 60$ per share and later increased the offer to $\$ 72$ per share).

136. For example, in the ongoing bid by AT\&T to take over NCR, AT\&T increased its bid from $\$ 90$ to $\$ 110$ per share, even though no competing offeror emerged. Shapiro, A.T.\& T. Raises Bid for NCR, N.Y. Times, Apr. 22, 1991, at C1, col. 6. Similarly, the French company Schneider S.A. increased its offer to Square D Co. from $\$ 78$ to $\$ 88$ per share in order to overcoine opposition to the acquisition. Miller, Square D Accepts Sweetened Bid of \$2.23 Billion from Schneider, Wall St. J., May 13, 1991, at A3, col. 1; see also Nathan \& O'Keefe, supra note 1, at 119 (speculating that the increase in takcover premiums from 1974 to 1985 was due to an increase in "the heterogeneity of investors' beliefs about firm value, [which caused] an increase in the slope of the transactions supply curves for securities").

137. See DeAngelo, DeAngelo \& Rice, Going Private: Minority Freezeouts and Stockholder Wealth, 27 J.L. \& ECON. 367, 401 (1984) (going-private transactions studied did not result in systematic exploitation of minority shareholders); Lowenstein, Management Buyouts, 85 CoLUM. L. REV. 730, 736 (1985) (the larger the conpany, the more likely it is that a proposed buyout will trigger third-party offers to create an auction beneficial to shareholders); see also Coffee, supra note 8, at 86-93 ("price" of buyout may be lower because of lower risk involved). 
ment seeks to preempt the possibility of a higher outside bid. Or it may be that investors hold out for larger premiums because they realize that a third-party bidder is likely to bid inore than management. ${ }^{138}$

In any case, the downward-sloping demand hypothesis suggests that if the premiums paid to shareholders in manageinent buyouts are indeed equal to those paid in connection with third-party offers, shareholders are receiving a windfall in connection with completed offers. ${ }^{139}$ This, in turn, unduly discourages management offers by requiring that they be made at higher premiums than shareholders would voluntarily accept if management were not effectively required to pay outsider prices. ${ }^{140}$

\section{Market Mechanisms}

Certain mechanisms built into the stock market itself offer still more evidence in support of the downward-sloping demand hypothesis.

\section{Limit Orders}

Traders frequently enter orders with exchange specialists to buy or sell when a particular stock reaches a designated price. ${ }^{141}$ Stock exchanges have well-estabhshed procedures to deal with these "limit orders," and recently the over-the-counter markets have taken steps to handle such orders as well. ${ }^{142}$ In short, the stock markets are organized, in part, on the assumption that investors have different opmions about the proper price for a given share of stock.

The importance of the limit-order process, and the increasing controversy surrounding it, demonstrates further that imvestors take very seriously their mdividual pricing behefs. The importance attached to such orders is supported by the fact that the duty to record and execute such orders is assigned to the "exchange specialist," the key player in charge of maintaining an orderly market. ${ }^{143}$ Furthermore, it is noteworthy that such orders have priority over other orders, and are required to be executed first. ${ }^{144}$ Perhaps inost telling of all is that knowledge of the contents of the limit order book is closely guarded and apparently quite

138. Note that the law requires management to open up the bidding to all comers once the company is put up for sale to any bidder. See Revlon, Inc. v. MacAndrews \& Forbes Holdings, 506 A.2d 173, 184 (Del. 1983) (finding that management may not deal preferentially with any one bidder; if the other bidders are not hostile, market forces should be able to operate freely).

139. See Booth, supra note 9, at 653-56.

140. Id.

141. See generally Poser, Restructuring the Stock Markets: A Critical Look at the SEC's National Market System, 56 N.Y.U. L. REV. 883, 927-31 (1981) (discussing proposed nationwide protection of limit orders).

142. Id.

143. Id. at 928.

144. Id. at 928-29. 
valuable. ${ }^{145}$ Indeed, when Congress enacted legislation in 1975 to establish a national market system, one of the primary goals was to aclieve nationwide protection against the execution of limit orders at an inferior price, irrespective of the particular exchange on which the limit order was booked. ${ }^{146}$ This particularly controversial reform is probably the single least implemented directive in the 1975 legislation, in large part because it is unclear low to afford access to the limit order book and low to coinpensate New York Stock Exchange (NYSE) specialists for the loss of their monopoly in that regard. ${ }^{147}$ While none of this directly proves that investors actually hold differing opimions as to the value of the saine share of stock, it does suggest that investors and market professionals believe that stocks have downward-sloping demand.

\section{Shareholder Vote Requirement for Certain Large Issues}

Other evidence supporting the downward-sloping demand hypothesis is found in certain exchange rules regulating new issues of stock. The NYSE, for exainple, requires a shareholder vote for any new issue of shares in excess of $18.5 \%$ of the quantity of sliares outstanding. ${ }^{148}$ The American Stock Exchange has a sunilar restriction, requiring a vote if the issuing company proposes to imcrease its outstanding stock by more than $20 \% .{ }^{149}$ In both cases, the vote is required regardless of what state corporation law may allow. Although the exchanges have traditionally proinulgated histing rules that regulate aspects of corporate governance, such as the one-share, one-vote rule, the theory behind the new-issue rule is unclear. Most listing rules are probably intended to make shares somewhat more uniform in the riglits they carry, and thus more readily tradable. ${ }^{150}$ It is, however, difficult to justify the rules relating to new issues on this basis.

A much nore likely rationale for these rules is that they are designed to avoid what might be called "supply shock," a price depression that arises when significant ainounts of new stock are floated onto the market. Once again, uuless the downward-sloping demand hypothesis is correct, such rules would hardly be necessary. In a world of level deinand, the new issue of stock should have no effect on market price.

145. See id. at 928 (suggesting that politics slowed the establishment of a centralized systein, because exchange specialists, who derived significant incoine from executing the linnit orders in their separate books, would no longer control the execution of their orders).

146. Id. at 928-29.

147. See supra note 145.

148. New YoRK Stock EXchaNge, LISTEd COMPANX MANUAL \$ 312.00 (1983).

149. AMERICAN STOCK EXchaNGE, COMPANY GuIDE $§ 712$ (1983).

150. By ensuring a minimum level of uniformity, the exchange relieves investors and nember firms from the need for extensive research about what rights a given share of stock carries, and allows them to concentrate on the financial performance of the issuing company. See Federal Tender Offer Law, supra note 12, at 756 (discussing the one-share, one-vote rule for tender offer regulation). 
Thus, at the very least, exchange rules dealing with new issues of shares indicate that those who trade shares most actively believe in downwardsloping demand. ${ }^{151}$

\section{E. Company-Specific Phenomena}

\section{Increase Accompanying Listing on the Standard \& Poors 500}

Recent studies indicate that stocks that are added to the S\&P 500 enjoy an immediate and permanent gain, presumably as a result of being associated with the other 499 stocks. ${ }^{152}$ While this gain no doubt arises at least in part because investors and traders depend on the S\&P 500 to formulate portfolios, thus generating more demand for the included stocks, that is precisely the point. Unless demand for stocks tends to slope downward, increased demand would have no effect on price. A similar effect might be expected in connection with the listing of shares for trading on an exchange. Indeed, it would not be surprising if histing on a more prestigious exchange, like the NYSE, led to a greater mcrease in price than listing on a less prestigious exchange. Curiously, such effects have not been conclusively fonnd. One possible explanation for why histing does not, in and of itself, attract new investors is that listmg provides no new information about the company nor does it inplicate the stock for any widely used investment strategy. ${ }^{153}$

151. A phenomenon that artificially inflates the supply of available stock is short selling. Investors, betting that a stock's price will fall, "borrow" shares for immediate sale. Replacement stock must eventually be purchased to replace the "borrowed" shares, but in the meantime the short seller is in a position to drive down the price of the stock by flooding the market with the borrowed shares. The SEC is currently considering whether to require investors to disclose when they have a short position of a significant percentage of a company's shares. Salwen, Torres \& Newman, SEC Thinking About Making Short-Sellers Go Public, Wall St. J., May 24, 1991, at C1, col. 3.

152. See Shleifer, Do Demand Curves for Stocks Slope Down?, 41 J. FIN. 579 (1986) (attributing the significant abnormal return generated by stocks that are newly included onto the S\&P 500 to the downward-sloping demand hypothesis). Stocks are occasionally added to the index when vacancies occur because a formerly listed company has been taken over or bought out and is thus no longer traded publicly. A company may also gain entry to the index by displacing a smaller company.

153. There is considerable disagreement as to whether histing on an exchange (or on a particular exchange) affects stock prices. See Voting Rights Listing Standards-Proposed Disenfranchisement Rule, Exchange Act Release No. 24,623, [1987 Transfer Binder] Fed. Sec. L. Rep. (CCH) I] 84, 143 (June 22, 1987) (summarizing studies indicating that listing and delisting do not result in gains and losses in share prices). These studies are not necessarily dispositive of the idea that histing on an exchange could generate real gains, however. Evolution in the trading market has proceeded at such a rapid pace over the past twenty years that existing studies are clearly outdated. Id.; see also Norlin Corp. v. Rooney, Pace Inc., 744 F.2d 255, 267-69 (2d Cir. 1984) (delisting constitutes irreparable harm for purposes of granting imjunction). Moreover, because the exchanges have inore or less abdicated their role as monitors of, or reputational intermediaries for, listed companies in recent years (if they ever really performed it), there is no reason to expect existing studies to show a significant price effect associated with listing on an exchange or on a particular exchange. See, e.g., Federal Tender Offer Law, supra note 12, at 756-58 (discussing the decision by the NYSE to abandon its one-share, one-vote requirement for listing). It may be too that the exchanges have been upstaged by the indexes. See White, Mid-Size Stocks Seen Rating New Respect as S\&P Unveils the 


\section{Differing Sensitivities to Market Risk of Larger and Smaller Companies}

The downward-sloping demand hypothesis also suggests an explanation for the contimued hquidity of larger companies during the 1987 market crash. ${ }^{154}$ If demand for stock does in fact slope downward, then different companies' demand curves presumably have different slopes. It seems only natural that shareholder opinions will differ less markedly in connection with larger companies than in connection with smaller companies since draniatic changes in fortune are less likely in larger coinpames. Therefore, the demand curves of larger companies will likely have a gentler slope, will enjoy more contimuous markets, and will continue to trade even under volatile market conditions.

The idea that demand curves for different stocks vary in slope is consistent with one of the basic tenets of modern finance theory: all stocks tend to move with the market, but to varying degrees. The tendency of each stock to move with the market has been quantified. A stock that has a history of moving by the same percentage as the market, whether up or down, is said to have a "beta" coefficient of 1.0. A stock that moves only half as much as the market has a beta of 0.5 , while a stock that moves twice as much as the market has a beta of 2.0.155 There is, however, a contradiction in the financial theory from which such arguments flow. The problem is that if the level-demand hypothesis is correct, then there is no reason why stocks should have varying beta coefficients. If investors imvest only im portfolios and are imdifferent to various stocks other than with regard to the fit of a particular stock in a portfoho, then stocks would not liave varying tendencies to move with the market.

The notion that companies have different sensitivities to market risk-that is, different beta coefficients-is difficult to explanı unless stocks have downward-sloping demand. The downward-sloping demand liypothesis suggests that an outside event, sucl as clianging interest rates or increased worry over the state of the economy, will have varying effects on the stock prices of companies with differently sloping demand

400 in Its Latest Index, Wall St. J., Jun. 5, 1991, at C1, col. 3 (discussing an apparent demand for new indexes); White, The Index Boom: It's No Longer Just the S\&P 500-Stock Index, Wall St. J., May 29, 1991, at C1, col. 4 (same). However, if stock exchange listing rules were well crafted and effectively insured that listed coinpanies had a particular set of characteristics valuable to investors, there is no reason to believe that being listed on a particular stock exchange would not enhance the value of a stock. Thus, as $I$ have suggested elsewhere, the stock exclranges could in theory regulate takeovers quite thoroughly and effectively by setting up listing categories that are responsive to the peculiar thrcats faced by coinpanies in different stages of developinent. See Federal Tender Offer Law, supra note 12, at 758-61.

154. See generally SEC, supra note 93 (discussing the inarket impact of issuer repurchases in the wake of the 1987 crash).

155. See J. LoRIE, P. DODD \& M. KIMPTON, supra note 3, at 33-41. 
curves. This would be true even though the new information was the same for all companies. For example, if a particular piece of news affected the perceptions of, say, $10 \%$ of the investor population, and the entire $10 \%$ at the margin were thus induced to buy or sell, one would expect a more draniatic price change in a coinpany with a steeper curve than in a company with a flatter curve. If, on the other hand, demand curves are perfectly fiat as others have suggested, it would be hard to see any reason why in a world of well-diversified investors some companies would change in value more than others.

Probably the single greatest point of contention as to the validity of the downward-sloping demand hypothesis is that if it is true, it contradicts the idea that investors do not (and should not) trade on the basis of company-specific information. Indeed, downward-sloping demand depends directly on the fact that there are a significant number of investors who trade on the basis of behefs about the value of individual compames. This is intriguing because it seems to suggest mass irrational behavior. It has been fairly well proven that the inarket cannot be beaten, and thus that the market does not compensate investors for company-specific or "alpha" risk. ${ }^{156}$

Yet casual empiricism suggests that many investors do invest on the basis of company-specific information. Moreover, studies show that alpha risk accounts for about two-thirds of price movement. ${ }^{157}$ It seems incredible that, if such a large proportion of price movement is attributable to company-specific factors, there are not imvestors who make significant returns trading on it. Indeed, where does so much company-specific volatility come from if there is not a good deal of company-specific trading going on?

There is something shightly backward about the assertion that so many investors behave irrationally. We can call traders who trade individual stocks irrational, but that does not change the fact that they do it. The real challenge is to explani why apparently irrational behavior persists. The answer is really fairly simple. The market is the traders who compose it, and the average return on stocks is ultimately the average of what thousands of well-informed (as well as misinformed) traders do. Thus, the notion that one can beat the market consistently is rather like the idea that all the children in Lake Wobegon are above average. In

156. See, eg., R. POSNER, supra note 10, at 405-15. This is not to say that investors who engage in stock-picking necessarily lose money in absolute terms. Clearly, the market goes up over time. Thus, even an investor who picks individual stocks will typically make inoney over time. What this ineans, however, is that the market does not compensate for alpha risk, and that on average no one consistently makes returns in excess of the market rate. Therefore, stock-picking investors tend on average not to make as much money as they would if they simply "bought the market" by investing in, say, an index fund.

157. See J. LORIE, P. DODD \& M. KIMPTON, supra note 3, at 38. 
short, there is nothing at all surprising about the fact the no one beats the market consistently. But it does not necessarily follow that it is irrational to try.

\section{F. Marketwide Phenomena}

Finally, there is plenty of anecdotal evidence suggesting that supply and demand affect stock prices generally, as opposed to the prices of individual stocks. There is also evidence that supply and demand affect the prices of other financial instruments. For example, it has been argued that the most recent bull market was fueled in part by the declining supply of equities. ${ }^{158}$ The decline itself was presumably due in part to buyouts and the use of debt financing both by primary issuing coinpanies and by bidders for purposes of financing takeovers. More recently it was predicted that the junk bond market itself would be affected by the recent wave of buyouts. The thought was that imterest rates on high-risk debt would likely rise because of the increased supply being floated onto the market.

Interestingly, the idea that the prices of equities and debt as whole classes are affected by supply and deinand is inuch less controversial than the idea that such forces affect individual securities. ${ }^{159}$ Indeed, many commentators who argue that individual stocks have level demand seein to assume that there are many close substitutes for any given share of stock. ${ }^{160}$

Nevertheless, the more fundamental arguinents for why stocks have level deinand should apply both to individual stocks as well as to stocks

158. See, e.g., Winans, Stock Market Loses Vital Corporate Crutch, Wall St. J., July 23, 1990, at C1, col. 3 (declining supply of equities from 1984 through 1989 reduced aggregate value of NYSE issues by an average of $6.5 \%$ per year, accounting for more than one-fifth of the $115 \%$ increase in market prices over the same period). The Winans article was itself identified as a cause of the 56 point drop in the Dow Jones Industrial Average on the day it appeared. See also Torres, Rapld Stock-Supply Shrinkage Continues, Wall St. J., July 14, 1989, at C1, col. 3 (attributing the bullish stock market to the reduced supply of equities); Newman \& Torres, Corporate America's Eguity Avalanche Continues to Build at Breakneck Pace, Wall St. J., May 10, 1991, at Cl, col. 3 ("thirst for equity is adding inomentum to the avalanche of new stock issues"). But see Newman, New-Stock Sales Spree Continued in May, but Some Prices Are Cut, Wall St. J., May 31, 1991, at Cl, col. 3 ("surge in new stock offerings reverses the trend of the 1980s"); Lowenstein, Goldman Study of Stocks' Rise in '80s Poses a Big Riddle, Wall St. J., June 6, 1991, at C1, col. 3 (expressing doubt that the total amount of shares outstanding shrank sufficiently to cause a scarcity of shares). See generally Jensen, Eclipse of the Public Corporation, HARv. Bus. Rev., Sept.-Oct. 1989, at 61 (describing the trend away from public ownership of corporate equity).

159. See, e.g., Coffee, supra note 12 (discussing downward-sloping demand for equity in general). For some anecdotal evidence that supply and demand affect the prices of whole categories of investments, see Siconolf, First-Half Stock, Bond Offerings Soared 59\%, Wall St. J., July 1, 1991, at C1, col. 3; Newman \& White, Big Money Is Fueling Small-Stock Rally, Wall St. J., April 22, 1991, at C1, col. 3; Anders, RTC Is Unloading Its Junk Bonds at Furious Pace in a Seller's Market, Wall St. J., April 15, 1991, at C1, col. 4.

160. See supra note 69. 
as a class. The argument is essentially that since it is impossible to beat the market consistently, it is not only impossible to pick misvalued stocks, but also impossible to predict whether the market as a whole will go up or down. Those who argue that demand is level as to particular stocks but downward-sloping as to the market as a whole imphicitly accept one idea of efficiency while rejecting another. Although consistency may well be the hobgoblin of hittle minds, it is nonetheless unclear why the efficient market should imply one thing for individual stocks and the exact opposite for stocks as a class.

To sum up, in addition to the evidence that new issues and block sales of stock force down prices, and that investors seem to care more about bad news than good news, there are other market phenomena that support the downward-sloping demand hypothesis. Issuers repurchase their shares in a variety of circumstances to raise or support the price of their shares. Bidders pay huge premiums for target shares, and pay larger premiums for larger percentages of shares. The markets themselves are organized on the assumption that the downward-sloping demand hypothesis is correct. Finally, evidence indicates that on both a company-specific and a market-wide basis, demand for various kinds of securities slopes downward. All of these rather simple facts strongly suggest that shareholders, and indeed all investors, have differing opmions as to what their shares and other investments are worth. In other words, there is every reason to beheve that stocks are like other commodities.

\section{IV \\ The IMPlications of DoWNWARD-SLOPING Demand}

As noted at the outset, the market hypothesis and the misinvestment hypothesis suggest different theories as to how tender offers and defensive tactics should be regulated. If the misinvestment hypothesis is correct, tender offers should be encouraged and defensive tactics condemned. If the market hypothesis is correct, a contrary pohicy would seem more appropriate. But, if the two are in fact one, as the evidence in support of the downward-sloping demand hypothesis seems to indicate, then perhaps neither of the polar policy alternatives is indicated.

Ultimately, the downward-sloping demand hypothesis is more consistent with the market hypothesis, as it has typically been set forth, than it is with the misinvestment hypothesis. This is not to deny that the two are in fact one. The downward-sloping demand curve can be characterized as arising from the fact that each next stockholder is naturally less confident of management, in the obvious sense that each next stockholder is willing to invest ouly at a shightly lower per share price. And 
one can therefore argue that this view is more akin to the mismanagement hypothesis than it is to the market hypothesis. But im the end, the important difference between the two views is that the market hypothesis suggests that undervaluation arises naturally, whereas the mismanagement hypothesis suggests that undervaluation can be avoided by better management. The thesis here is that what appears to be mismanagement is simply the natural outgrowth of having sold too much stock or having failed to repurchase it when conditions changed. The discussion that follows explores this concept, as well as the implications of the downwardsloping demand curve in several important regulatory contexts.

\section{A. Implications for Tender Offer Regulation}

\section{The Law Should Treat Large and Small Companies Differently}

One interesting implication of downward-sloping demand is that takeover defense regulation should perhaps be more stringent for large companies than for small ones. In other words, it may be that takeover defenses that are appropriate for one sort of company may be abusive for another.

Professor Gilson notes that the managements of large and small companies tend to use different mechanisms im order to secure control. Management of a mature company is more likely to use a leveraged buyout to go private, while management of a growing company is more likely to use a dual-class recapitalization to reduce the votimg rights of a substantial portion of the outstanding shares. ${ }^{161}$ As Gilson points out, "[b]oth transactions accomphish the desired goal of shifting or fixing control." 162

Gilson surmises that the differing preferences are the result of differing agency costs present in mature and growing companies. In the mature firm, with few growth prospects and hittle need for new capital, inanagement may be teinpted to slack off and extract high salaries and benefits. It need not please its shareholders except in order to avoid a takeover. Because of this, the shareholders of the mature company require a firm commitment either in the form of cash or debt securities. ${ }^{163}$

On the other hand, in a company with growth potential, manage-

161. See Gilson, Evaluating Dual Class Common Stock: The Relevance of Substitutes, 73 VA. L. REV. 807, 824-31 (1987). In a dual class recapitalization, the company issues nonvoting stock or reduces the voting rights of public shareholders, while preserving the option to raise additional equity capital. As Gilson points out, in the end the two transactions are economically equivalent for the outside shareholders, in that they either receive a larger stream of dividends in excliange for their voting rights or they receive a premium for their shares sold in a leveraged buyout. See id. at 813-14.

162. Id. at 813 .

163. Id. at 823-25. 
ment's interests are more likely to coincide with those of the shareholders. There is every reason to keep the shareholders happy and stock prices up in order to raise new capital. Furthermore, there are also good reasons for management to work hard and to keep salaries and perquisites to a minimum, if such forgone consumption can, im effect, be reinvested in the company and withdrawn later as deferred compensation in the form of higher-priced and hquid publicly held shares. ${ }^{164}$ The shareholders in the growth company are thus less concerned about management's agenda and are relatively happy to trade in their voting stock for nonvoting stock. ${ }^{165}$

The differences that Professor Gilson has outlined also suggest that demand for the stock of smaller and newer companies slopes more steeply than demand for the stock of mature companies. While agency costs may be lower in smaller and newer coinpanies, that does not necessarily mean that the stock of such companies is less likely to be discounted in the market. Indeed, it may mean just the opposite. Because agency costs are less of a worry, the price of the stock may be more sensitive to fluctuations in the fortunes of the company. A mature company with relatively slack management may be able to respond to adversity by tightening its belt, whereas a smaller and newer company that is already operating with a fairly tight belt may not be able to smooth out its results so readily. ${ }^{166}$

Similarly, a smaller and newer company can grow at a far faster pace than can a larger company; any given dollar mcrease in earnings or cash flow or asset value will represent a larger percentage of a smaller beginning number. It stands to reason, then, that an investor will receive a draniatically varied return on a share of stock in a smaller and newer coinpany than the return from an investment in the stock of a mature company. For that reason alone, investors are mucli more likely to hold more widely varying views as to the value of the shares of a company. Moreover, smaller companies are less actively traded, and the market for the stock of such companies is presumably less efficient. Thus, shareholders in such companies are likely to differ more in their opinions of what constitutes an adequate offer.

164. Id. at 825-32.

165. See Federal Tender Offer Law, supra note 12, at 748. A preliminary study recently prepared by one of my students determined that passage of the Maryland business combination statute had less of a negative impact on the price of shares of smaller companies than it did on the share price of larger ones. C. Rudolphi, The Maryland Business Combination Act and Shareholder Wealth (1991) (unpublished manuscript) (on file with the author). The findings of the study support the idea that takeovers are perceived as more of a threat to shareholder wealth in smaller companies. It may be, too, that smaller coinpanies are naturally more likely to have the potential for exploiting economies of scale, and thus have a more behevable need for capital than larger companies. See text accompanying note 64, supra.

166. See Black, supra note 5, at 609-10. 
These observations about the likely slope of shareholder demand curves suggest that the potential for abuse differs for different-sized companies in the context of tender offers. Therefore, tender offer rules should also vary with a coinpany's size. For smaller, riskier companies with steeper curves, partial and two-tier bids are potentially inost coercive. Shareholders at the upper end perceive that they have more to lose (and gain) by holding out. Moreover, the danger of lootimg after control is achieved would seem to be enhanced. The smaller the target, the more susceptible it is to being operated as a captive subsidiary. Thus, the shareholders justifiably fear the consequences of a partial bid and are more likely to tender early for what they perceive to be a less attractive offer than would the shareholders in a larger company. The indication is thus to prohibit coercive offers for small companies or at least to permit more potent defenses. ${ }^{167}$

On the other hand, shareholders in larger companies with flatter curves are far less subject to coercion. They stand to lose less by missing the chance to tender, and the potential for looting a large company is usually smaller. The indication, then, is to allow a wider range of bids for larger coinpanies and to restrict permissible defensive tactics.

\section{The Misguided Quest for Equal Treatment of Shareholders}

The essential idea behind the downward-sloping demand hypothesis is that different shareholders place different values on their stock. Therefore, it inay be wrong for the law to seek to treat all shareholders equivalently. One interestimg angle from which to consider this is the management buyout. Critics have argued that if inanagement is willing to pay a premium for the coinpany because the company is really worth more than the market indicates, then inanageinent is implicitly in breach of its fiduciary duty by failing to pursue that value for all the shareholders and instead capturing it for itself. ${ }^{168}$ On the other hand, if demand curves do in fact slope downward, there will always be a differential in perceived value, and those on the upper part of the slope will naturally, and quite innocently, be interested in buying out those on the lower part

167. If managers of growing companies have fewer conflicts of interest with their shareholders, a takcover bid is much more likely to depend on coercive techmiques since the offered premium is less likely to be motivated by slack management. Management resistance to a takeover is thereforc much more justified.

168. See, eg., Brudney, A Note on "Going Private," 61 VA. L. Rev. 1019, 1038 (1975); Brudney \& Chirelstein, supra note 12 , at 1359 . It bears noting, however, that some of the same commentators have also argued that any peculiar regulation of sales of coutrol at a premium will inpede the transfer of corporate assets to their lighest-valuing owner, and will thus be inefficient. Compare Easterbrook \& Fischel, Corporate Control Transactions, 91 YALE L.J. 698, 726-27 (1982) (efficient market ineans that management buyout at premiun represents gain for shareholders), with Easterbrook \& Fischel, supra note 5, at 1194-99 (efficient market correctly prices shares, and slareholders would therefore tender for minimal premium). 
of the slope. As previously noted, the downward-sloping demand hypothesis suggests that buyouts would naturally occur at lower premiums than third-party sales because in a buyout the bid need not be high enough to satisfy management and other inajor shareholders. ${ }^{169}$ The downward-sloping demand hypothesis thus suggests that management buyouts are a good deal inore defensible than has been argued.

Similarly, the downward-sloping demand hypothesis suggests that sales of control at a premium are perfectly legitimate. While the active market for corporate control has inade this old issue seem quaint, the fact remains that outside the downward-sloping demand hypothesis, no one has satisfactorily explained why a controlling shareholder should be privileged to sell out at a bonus and should not be required to share the premium with the remaining shareholders. The downward-sloping demand hypothesis offers an explanation of the source of the additional value perceived by a controlling shareholder. ${ }^{170}$

In sum, the downward-sloping demand hypothesis raises general questions about the value of equal treatment as a norm of corporate law. It suggests that statutory scheines such as the Williams Act, which are designed to assure equal treatment ainong shareholders, are wrongheaded. Indeed, given that downward-sloping demand einanates froin shareholders themselves, the rules of law that impose equal treatment inay actually detraet froin shareholder wealth. ${ }^{171}$ That is, such rules may sometimes get in the way of transactions that shareholders and other potential parties would like to see consummated. ${ }^{172}$

\section{The Fallacy of the "Fair Price"}

Much of the current law addressing the various controversies arising in connection with corporate-control transactions is based on the assumption that there exists some objectively fair price for a share of stock. ${ }^{173}$ The downward-sloping demand hypothesis, however, suggests that this approach is misguided; such disputes should instead be resolved by focusing on whether the parties reached a bargam that could have been expected after fair negotiation. Although such an inquiry can be difficult where one side is a collection of investors with discrepant opin-

169. See supra text accompanying notes 137-39.

170. See Booth, $A$ Note on Individual Recovery in Derivative Suits, 16 Pepperdine L. Rev. 1025, 1037-41 (1989).

171. Fischel, supra note 12, at 19.

172. Federal Tender Offer Law, supra note 12, at 713-15.

173. See, e.g., infra notes 181-84 and accompanying text (discussing Armstrong v. Marathon Oil, 32 Ohio St. 3d 397, 513 N.E.2d 776 (1987)); see also TSC Indus. v. Northway, Inc., 426 U.S. 438 (1976); Mills v. Electric Auto-Lite Co., 552 F.2d 1239 (7th Cir.), cert. denied, 434 U.S. 922 (1977). 
ions as to value, the group can be treated fairly on the average. ${ }^{174}$ Furthermore, the other party, whether management or outside bidder, should not necessarily be required to disgorge all of the profit it anticipates. ${ }^{175}$ A comparison of two opinions, Weinberger v. UOP, Inc. ${ }^{176}$ and Armstrong v. Marathon Oil, ${ }^{177}$ demonstrates the current disagreement over underlying theory, and how this has, in turn, led to dramatic differences in the ways courts resolve these issues.

The 1983 Delaware Supreme Court decision in Weinberger is probably the most striking example of judicial acceptance of the downwardsloping demand hypothesis in this context. The court in that case stated that a cash-out merger was presumed fair if it had been ratified by a fully informed majority-of-the-minority vote. ${ }^{178}$ The decision reflects the recognition that a cash-out merger should be treated as a negotiation between two parties holding different opinions as to the value of the same good.

Perhaps most important is the court's accominodation of different shareholder opinions through the medium of the minority vote. The vote would be a futile gesture if there were no reason to expect minority shareholders ever to vote down the sale of their shares at the typically substantial premiums offered. Moreover, the vote also accommodates the fact that there is no single fair price even as among the minority shareholders. All that is required is that minority shareholders be satisfied on the average. ${ }^{179}$ Finally, in the same case the Delaware court modified the longstanding approach to the appraisal of dissenters' shares, effectively ridding Delaware law of the presumption that market price is adequate compensation if the stock is actively traded. ${ }^{180}$

In stark contrast, the Ohio Supreme Court in Armstrong ignored altogether the possibility that the market can be wrong. The case grew out of the earlier takeover of Marathon Oil by United States Steel, which

174. See, e.g., Stout, supra note 9 , at $685-90$ (arguing that the law should seek to insure that a tender-offer premium accurately reflects the average reservation price of the population of target shareholders rather than the efficient-trading market price). I have argued elsewhere that rules governing tender offers suffer from precisely the problem that Stout identifies. Federal Tender Offer Law, supra note 12, 739-48.

175. See generally Booth, supra note 9, at 639-45.

176. 457 A.2d 701 (Del. 1983).

177. 32 Ohio St. 3d 397, 513 N.E.2d 776 (1987).

178. Weinberger, $457 \mathrm{~A} .2 \mathrm{~d}$ at 703.

179. See generally Booth, supra notc 9 (discussing management buyouts in light of the assumption that different shareholders value the stock differently, and thus there is no one fair price). See also PRINCIPLES OF CoRPORATE GovernanCE: ANALYSIS AND RECOMmendations $\S 5.02(a)(1)$ comment at $30-31$ (Tent. Draft No. 5, 1986) ("fairness is often a range, rather than a point"); REvised MODEL BuSINESS CORP. ACT \$ 8.61 official comment (Supp. 1989) (same); Chazen, supra note 12, at 1439; Takeover Premiums, supra note 12, at 1249.

180. Weinberger, 457 A.2d at 712-15. 
had come to Marathon's rescue after an unwanted bid by Mobil. ${ }^{181}$ In Armstrong a group of Marathon shareholders had dissented from the merger between Marathon and United States Steel, and had opted to receive cash for their shares after judicial appraisal. ${ }^{182}$ After an exhaustive (and indeed exhaustimg) review of theoretical hiterature, the court ruled that because Marathon stock was actively traded and presumably efficiently prieed, the shareholders were entitled only to the market value of the shares before the announcement of the tender offer and subsequent inerger. ${ }^{183}$ While the decision is diametrically opposed to the Delaware court's landmark decision in Weinberger and is utterly inconsistent with the possibility of downward-sloping demand, it is perfectly consistent with the well-accepted notion that because the market is efficient, any premium over the inarket price ought to be enough to induce a shareholder to tender. ${ }^{184}$

It seens fair to say that Weinberger is more in kecping with the market hypothesis, while Armstrong is inore in keeping with the misinvestment hypothesis. In any event, both of these recent cases cannot be correct. ${ }^{185}$ The fact that they are both on the books deinonstrates that there is considerable disagreeinent (or confusion) as to why takeovers arise and the source of takeover premiums. Most important, the disagreement illustrates that the way we regulate transactions involving corporate control is affected by the theory through which we view the facts. In light of the evidence in support of the downward-sloping demand hypothesis, this comparison suggests that a reevaluation of the case law in this area is appropriate.

\section{B. Implications for Regulation of Capitalization}

The downward-sloping deinand hypothesis has implications outside the area of corporate takeovers. One area of particular interest relates to capitalization levels.

181. Armstrong, 32 Ohio St. 3 d at $398-400,315$ N.E.2d at $778-80$.

182. Id. at 400,315 N.E.2d at 780 .

183. Id. at $412-13,315$ N.E.2d at $789-91$.

184. See supra text accompanying note 70; see also TSC Indus. v. Northway, Inc., 426 U.S. 438, 462-63 (1976).

185. Although not enunciated in the case, one possible justification for the result in Armstrong is that the court may have viewed the dissenting shareholders as free riders who figured that in the end they could not get less than the price paid in the inerger, but they might get more. As I have argued elsewhere, increasing rehance on shareholder voting may require that the appraisal remedy be somewhat curtailed to prevent shareholders from initially voting against a transaction, in order to have a shot at a still higher price. See Booth, supra note 9, at 657-58. 


\section{The Link Between Shareholder Dividend Preferences and Optimal Capitalization Levels}

As should be clear from the earlier discussion of the irrelevance proposition, the downward-sloping demand hypotlesis offers an explanation of why shareholders might value dividends, and, similarly, why share repurchases are a sensible use of company money. ${ }^{186}$ The downward-sloping deinand hypothesis suggests that investors may be averse to dividends in soine cases, but have a strong preference for thein in others. ${ }^{187}$ Shareloolders in a growing company that needs capital will generally be averse to dividends, while shareholders in a inature company that does not need capital will prefer dividends. ${ }^{188}$

Casual observation bears this out. Ordinarily investors react positively by bidding up the market price when a coinpany announces a repurchase program, but on occasion they react negatively. Such price changes can be attributed to signaling. For example, on one occasion when IBM announced that it would begin to repurchase its stock, the price fell because, according to market analysts, the repurchase program indicated that the company did not have the growtli potential that investors had thought it liad. ${ }^{189}$ Such signaling effeets are perfectly consistent with the downward-sloping demand hypothesis. Downward-sloping demand derives from the fact that some shareholders care about coinpany-speeific risk.

Whether a company is growing or mature, lowever, the downwardsloping deinand hypothesis suggests that slareholders will have a strong preference for issuers to keep the aggregrate value of stock outstanding to a minimum. This can be done either through payment of dividends, which reduce the total dollar value of outstanding shares, or through stock repurcliases, which reduce the number of shares outstanding. Since equity is the most expensive form of capital, the idea that slareholders prefer management to issue minimal amounts of stock only stands to reason.

By explaining how a company can becoine overcapitalized with common stock, the downward-sloping deinand liypotlesis may also solve a problen that has plagued discount theories generally: if discounts motivate takeovers, why do they disappear when the takeover occurs? ${ }^{190}$

186. See supra notes $48-51$ and accompanying text.

187. See supra notes 58-67 and accompanying text. In fact, this dichotomy may explain why it has never been proven one way or the other that shareholders do or do not have a preference for dividends. See Fischel, supra note 23, at 701-02.

188. Cf. supra text accompanying notes 161-67.

189. See IBM's Cash Problem: Too Much to Handle, Bus. WK., December 5, 1977, at 62; IBM Says It Purchased 500,000 of Its Shares In First 2 Months of '78, Wall St. J., Mar. 9, 1978, at 15, col. 2 (discussing drop in share price after IBM instituted its stock repurchase plan).

190. After all, if they did not, the buyer would find itself discounted and would become a prime 
The downward-sloping demand hypothesis suggests an answer to this mystery. It may be that takeover targets are simply overcapitalized with equity, and that savvy bidders use their own excess equity to finance the purchase of target equity, thus reducing the overall equity in the system. Moreover, if indeed shareholders care about how much stock a company has outstanding, several interesting possibilities follow.

\section{The Relationship Between Stock and Debt Capitalization}

Some commentators have suggested that takeover premiums are im fact redistributions of wealth from debtholders to stockholders. That is, stockholders are paid a premium for their shares because new management plans to pursue high-risk strategies that promise high profits to them but that also increase the risk of default for debtholders. ${ }^{191}$ If the downward-sloping demand hypothesis is correct, however, the gains that come from mergers and acquisitions or restructurings financed by borrowing may not come at the expense of debtholders, even though it may well be true that debtholders are harmed in the process. The gains that shareholders enjoy may simply be an expression of the fact that the fewer shares outstanding, the higher their value. And, the fact that debtholders see the value of their investinents fall may be nothing more than the result of the elimination of windfall gains from excess protection against default. ${ }^{192}$

As previously noted, the downward-sloping demand hypothesis explains why new capital is more expensive than existing capital. It also explains how a coinpany can be overcapitalized with common stock, a state of affairs that has sometimes been used as a justification for greenmail. ${ }^{193}$ Presumably the demand curve for stock is a good deal steeper than the demand curve for more serior securities, even of the same firm. Demand for all securities of any given issuer probably slopes downward along a continuum for the saine reasons that demand for stock slopes downward: because each next unit must be sold to a more reluctant investor, and because each next jumor security carries a bit more risk than the one before. Deinand for stock probably slopes downward more steeply than demand for other instruments simply because there usually are fewer variables to worry about with regard to other instruments. ${ }^{194}$

takeover target. Cf. Kraakman, supra note 4, at 920-25 (explaining how discounts invite takeover bids).

191. See McDaniel, supra note 5, at 304-07 (discussing fiduciary duty owed to bondholders by management in the event of a takeover bid).

192. See In re Chicago, Mil., St. P. \& Pac. R.R., 791 F.2d 524, 526-27 (7th Cir. 1986).

193. See, e.g., Cheff v. Mathes, 199 A.2d 548, 556 (Del. 1964).

194. See W. KLEIN \& J. COFFEE, supra note 21, at 232-36 (only risk that matters with regard to traditional debt instruments is default risk, whereas risk of stock relates to volatility of residual returus). 
Because of this steeper demand curve, the sale of additional stock will tend to be a much more costly way to raise new capital than the sale of other sorts of imstruments. For the same reason, the recent trend toward issuing debt in the form of junk bonds to retire common stock may make more sense than is commonly thought. That is, arguably a company that is overcapitalized with common stock can achieve real gains by substituting the stock with debt capital. Thus, efforts to limit the amount and quality of debt, whether through administrative regulation, enforcement initiative, or expansion of fiduciary duty, should be carefully considered at the very least. Unless one is prepared to say that the market simply does not work in this arena-a highly doubtful proposition when it comes to anything so liquid as securities-the better course is to keep hands off.

\section{Regulating Capitalization Levels and the Importance of Efficiency}

If shareholders do indeed care about the quantity of stock outstanding, perhaps management should even be held accountable for issuing too much stock, or for allowing too inuch stock to remam outstanding when alternative sources of financing are available. However, the idea that there is an optimal mix of debt and equity for any given company, although well accepted by corporate financial officers, is quite controversial within the academy. Due largely to the wide acceptance of the irrelevance proposition, academics generally agree that there is no ideal mix of debt and equity. Indeed, shareholders can themselves adjust manageinent's cliosen mix by combining their investment in the company's stock with risk-free government securities, or by borrowing on margin. Yet, few investors can borrow at rates that are comparable to those available to corporations. This suggests that even if mvestors are indifferent to dividends, they may not be imdifferent to how mucl debt a corporation carries.

The law is not, in fact, far froin imposmg such capitalization standards. For example, it has long been the rule that a corporation that admittedly has no need for available cash must distribute its cash to the shareholders. ${ }^{195}$ A similarly long-standing rule is that management will be held hable for knowingly making mvestments that cannot generatc a return. ${ }^{196}$ Recent cases even suggest that the courts will seriously consider charges that inanagement failed to invest at an adequate level of return. ${ }^{197}$ However, it is unlikely that the courts will go much further to

195. See, e.g., Dodge v. Ford Motor Co., 204 Mich. 459, 499-510, 170 N.W. 668, $681-85$ (1919).

196. See, e.g., Litwin v. Allen, 25 N.Y.S.2d 667, $677-78$ (N.Y. App. Div. 1940) (corporate directors have a fiduciary duty to "exercise some degrec of skill, prudence and diligence.").

197. See, e.g., Joy v. North, 692 F.2d 880, 896 (2d Cir. 1982), cert. denied sub nom. Citytrust v. Joy, 460 U.S. 1051 (1983); cf. Smith v. Van Gorkom, 488 A.2d 858, 890-93 (Del. 1985) (holding that 
expand such standards. The issues involved are traditionally protected froin prosecution except at the very edges by the business judgment rule. Because significant regulation is unlikely, inarket efficiency becoines a very important policy goal. In the absence of regulation, the market must regulate itself, and as a result, accurate indicators of value are important.

In a recent article, Professor Stout argues at length that, because stock does not function as a ineans of raising capital, efficiency is an unimportant policy goal. ${ }^{198}$ She notes that "[t]he econormic role which commentators most frequently ascribe to efficient markets is that of determining which firms can raise capital." "199 However, in light of the fact that firms tend to shun new issues of equity in favor of debt or internally generated funds, ${ }^{200}$ she concludes that the efficiency of the stock market is unimportant. In fact, she understates the case. In recent years there has been a net decrease in the amount of equity outstanding. That is, in many years corporations have repurchased more shares than they have issued. ${ }^{201}$

Her conclusion, however, that the efficiency of the stock market is unimportant, is simply wrong. In the first place, the idea of the efficient market is not confined to the market for equity securities. It extends to the debt market, and indeed many of its implications depend on the interrelationships between the two markets.

Second, because Stout fails to realize that internal funds are part of equity, ler notion that efficiency is unimportant, due to the relatively sinall inarket for new issues, is flawed. Equity lolders are the residual claimants on the firm. Thus, whatever is left over after all the bills are paid belongs to them. The market determines the value not only of what the company can fetch for another unit of stock, but also of the existing units. And it is the existing units that represent ownership of the largest single sourcc of funding: internally generated funds.

It is precisely because imternally generated funds are such an impor-

directors were liable for their failure to inform themselves of the risks obviously material to an investment decision).

198. Stout, supra note 9 , at 648 .

199. Id. at 693 .

200. One reason for this is that in the case of companies with equity outstanding, management and investment bankers believe that a new issue has the tendency to depress the price of outstanding stock. Id. at 653. Professor Stout also points out that during the years 1965 through 1982, corporations obtained $61 \%$ of funding froin operations and $36 \%$ from borrowing, leaving no inore than $3 \%$ that may have come from issuing equity. Id. at 648 \& nn.193-96. The fact that corporations are reluctant to resort to the equity market to raise capital is only natural. Equity lolders are, after all, the residual claimants on the firm and therefore take the greatest risk. Moreover, the fact that new equity is more expensive than retained earnings is itself an expression of the downward-sloping demand hypothesis. See supra text accompanying notes 49-57.

201. See supra note 158. 
tant part of equity that market efficiency is, and should be, a goal. Thus, the stock market may be better viewed as a tuning mechanism by which companies contimually adjust the level of equity at risk, possibly even primarily for purposes of satisfying senior creditors. In other words, it is arguable that the primary function of stock is as a dynamic indicator of value, rather than as a static source of capital. If so, the efficiency of the stock market is even more important than has often been thought.

\section{Regulating Market Manipulation}

\section{Explaining Stock-Specific Volatility}

With the advent of portfolio imvesting, which largely ignores the fortunes of particular companies in favor of the overall performance of baskets of stock, equity has become more like debt from the point of view of some investors, and ever fewer investors are willing to assess and assunie company-specific risk. The growth of index funds, which eschew all effort to construct a portfolio on the basis of any search for undervalued companies, has been well documented. Given the tremendous influence of financial theory, and indeed its impeccable logic for nost investors in most situations, it would be surprising if such a trend did not develop. It stands to reason, however, that if fewer stockholders trade on the basis of company-specific information, their opinions of value will vary inore widely and, assuming that the downward-sloping deniand hypothesis is correct, the deinand curve will have a steeper slope. Thus, the downward-sloping dentand hypothesis is much more consistent with narket volatility than the level-denrand hypothesis. Indeed, as previously noted, the level-demand hypothesis suggests that market volatility is an inexplicable mystery. The downward-sloping deniand hypothesis, on the other hand, is consistent with apparently increasing volatility in individual stocks, even at a tinie when the market as a whole renianis relatively stable. Thus, the downward-sloping denand hypothesis nay even help explani stock market crashes. ${ }^{202}$

\section{Reforming the Law of Manipulation}

The downward-sloping demand hypothesis also explains why the law relating to manipulation has been so confused. Simply put, the courts as well as enforcement agencies liave been torn, at least subconsciously, between the idea that stocks have one true price at any given

202. See R. Booth, Program Trading and the Stock Market 11-13 (1990) (unpublished manuscript) (on file with the author). J. Grundfest, Remarks at the Annual Meeting of the Association of American Law Schools, Section on Business Associations, in Washington, D.C., Jan. 4, 1991 (suggesting theory that crash may have been caused by sudden realization of traders that inuch recent buying activity had been inotivated by hedging strategies rather than by fundamental analysis). 
moment, and the idea that the price is in part a reflection of the demand for or supply of the stock.

The Supreme Court's recent decision in Basic Inc. v. Levinson ${ }^{203}$ asserts that the Securities Exchange Act of 1934 "was designed to protect investors against manipulation of stock prices."204 However, very few cases of inanipulation have been prosecuted. This is presumably because of the sheer difficulty of proving a manipulation case: ${ }^{205}$ a multitude of other factors may have caused a stock's price to move. ${ }^{206}$

The real reason, however, for the small number of stock price manipulation cases may be that there are serious doubts about what constitutes manipulation. The Exchange Act ouly outlaws transactions for the purpose of "pegging, fixing, or stabilizing" the price of a security in contravention of SEC rules. ${ }^{207}$ As Justice White points out in his dissent im Basic, Congress originally proposed to create a private cause of action for anyone who purchased or sold a security at a price affected by a misrepresentation. ${ }^{208}$ That provision was omitted from the final act because it did not require rehance. But there was an additional and more fundaniental problem with it: all sorts of things, including information, legitimately affect market prices. And often it is quite clear what effect disclosed information will have on the market. Does that mean that knowing disclosure of information that causes a reaction in the market constitutes manipulation? Hardly. ${ }^{209}$

In many cases, whether a given practice does or should constitute inanipulation depends directly on whether one subscribes to the downward-sloping demand hypothesis or the level-demand hypothesis. If the downward-sloping demand hypothesis is correct, then a repurchase of shares designed to raise the price of the stock would hardly be thought to be manipulative. The repurchase would simply have the effect of eliminating the lowest valumg investors from the population of current stockholders. It would have no manipulative effect on what stockholders think about the company. On the other hand, if one subscribes to the

203. 485 U.S. 224 (1988).

204. Id. at 230.

205. R. JENNINGS \& H. MARSH, supra note 113, at 624 .

206. See id. at 624-25; cf. Stout, supra note 9, at 696-98 (challenging the assumption that efficient markets accurately value stocks).

207. Securities Exchange Act, 15 U.S.C. $\S 78 \mathrm{i}(\mathrm{a})(6)$ (1988); see also Torres, Are "Slam Dunks" on Troubled Stocks a Foul?, Wall St. J., Feb. 1, 1991, at C1, col. 3 (regulators are scrutinizing "married puts," which are otherwise legitimate hedging trades that are subject to abuse when exercised in conccrt with release of bad news or a negative rumor about a company).

208. Basic Inc. v. Levinson, 485 U.S. 224, 257-58 (1988) (White, J., dissenting).

209. See, eg., Hundahl v. United Benefit Life Ins. Co., 465 F. Supp. 1349, 1362 (N.D. Tex. 1979) (holding that market reaction to the information content of managenent decisions was not a product of manipulation); see also Ayers, Back to Basics: Regulating How Corporations Speak to the Market, 77 VA. L. REV. 945 (1991) (discussing imphications of heterogeneous shareholder opinions for rules relating to corporate press releases). 
level-demand hypothesis, the supply of, or demand for, a particular stock should have no effect on its price. Thus, an increase in the price traceable to repurchases might well be thought to be manipulative.

\section{The Fallacious Presumption in Favor of Fixed-Price Offerings}

Whether or not the downward-sloping demand hypothesis is correct, it seems clear that numerous practices and regulations are based on the notion that it is. On the other hand, there are also regulations that are based on the assumption that deinand for stock is horizontal. As the preeminent textbook in the law of securities regulation points out, it is impossible to read the Seeurities Act of 1933 and to coine to any conclusion but that Congress adopted the fixed-price offering as the model on which to base the entire disclosure schemle. ${ }^{210}$ Moreover, after many years of agonizing, the SEC conferred the power to enforce underwriting agreements on the NASD, whereby all members of an underwriting group must refrain from affording any discount to particular purchasers. ${ }^{211}$

The bias for fixed-price offerings can be explained as rent seeking on the part of the securities industry. By arguing that fixed-price offerings are necessary to provide equal access for sinall investors, or to allow smaller regional brokerage houses to participate in offerings, the securities industry has prevailed on the regulators to enforce what announts to a price-fixing scheme and has captured a monopoly-like license for itself. ${ }^{212}$ But the fact that a regulatory scheme arises from rent seeking does not change the fact that it is there. Quite to the contrary, it suggests that a market based more on variable prices would einerge if allowed to. In other words, the distinct possibility that federal securities regulation (which in this regard is built on the assumption that demand for stocks is horizontal) acts as an elaborate price-fixing scheme, is, if anything, an

210. See R. JENNINGS \& H. MARSH, supra note 113, at 595. Consistent with that view, the SEC prohibited shelf registrations for years. See generally Banoff, supra note 45, at 135-45 (discussing the development of shelf registration).

211. See Fixed Price Offerings, supra note 113, at 81,761. In addition to fixed-price offerings, federal regulation of tender offers is quite clearly founded on the notion that there is or should be imposed a uniform price for all tendering shareholders. See Federal Tender Offer Law, supra note 12, at 712 (describing the attempt by Congress to ensure that shareholders faced with a tender offer would be treated equally).

It has also been suggested that the regulation of the securities markets is designed in part to support the price of stock. The relatively high margin requirements in the stock markets (compared to margin requirements in the futures markets) and the rules that restrict program selling seem to confirm this view. Booth, supra note 202, at 1-2. If it is the case that securities regulations provide a floor of sorts for the stock market, this too may enhance the illusion that demand for stocks is horizontal rather than downward-sloping.

212. See generally Banoff, supra note 45, at 155-76 (discussiug the pros and cons of Rule 415). 
additional reason to believe that the downward-sloping demand lyppothesis may be correct.

\section{CONCLUSION}

The thesis of this Article lias been that both of the leading explanations for the discounts that give rise to takeovers are true, and indeed that both explanations are nothing inore than alternative formulations of the same basic trutli: stocks, like otlier commodities, lave downwardsloping deinand curves. If indeed stocks do liave downward-sloping demand curves, then the price of a share is established by the opinions of the lowest-valuing current shareholder and the highest-valuing potential sharelolder. That is, the price of stock, like other goods, is set at the margin.

The downward-sloping curve predicts that most shareholders, indeed virtually all shareholders, have opinions as to the value of their shares that are higher than the market price. In other words, the inarket may be said naturally to undervalue shares. Moreover, downwardsloping demand also iniplies a good deal of distrust of management by shareholders. In other words, it may be that the market undervalues stock because the last sliare is necessarily sold to an investor who is willing to assume the greatest risk of managerial malfeasance. This is to say no more than the obvious: the more stock a company wants or needs to sell, the greater the discount that must be offered. And the more stock a bidder wants to buy, the greater the premium that must be offered. In short, the idea of the downward-sloping demand curve suggests that the mismanagement hypothesis and the market hypothesis for discounts are simply different ways of looking at the same phenomenon.

However, this realization has serious ramifications for the way the securities markets should be regulated. Specifically, in light of the downward-sloping deınand hypothesis, a critical reevaluation of tender offers, capitalization, and market manipulation would be a worthwhile undertaking. 